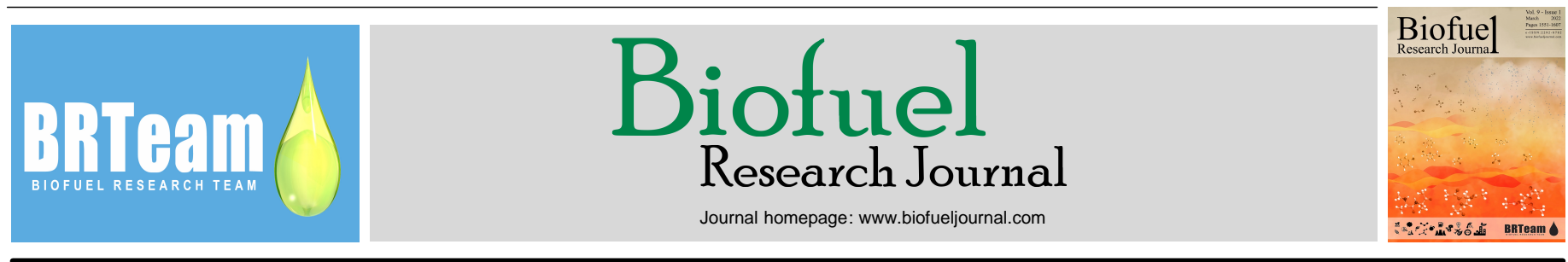

Review Paper

\title{
Producing hydrogen-rich syngas via microwave heating and co-gasification: a systematic review
}

\author{
${ }^{1}$ Department of Mechanical Engineering, Sebelas Maret University, Surakarta, Indonesia. \\ ${ }^{2}$ Department of Mechanical Engineering, Sultan Ageng Tirtayasa University, Banten, Indonesia. \\ ${ }^{3}$ Mechanical Engineering Department, Universitas Kebangsaan Republik Indonesia, Bandung, Indonesia. \\ ${ }^{4}$ Universitas Muhammadiyah Yogyakarta, Yogyakarta, Indonesia.
}

Imron Rosyadi $^{1,2}$, Suyitno Suyitno ${ }^{1, *}$, Albert Xaverio Ilyas ${ }^{1}$, Afif Faishal $^{1}$, Andres Budiono $^{1,3}$, Mirza Yusuf $^{4}$

\section{HIGHLIGHTS}

$>$ Role of microwave technology in gasification and co-gasification processes for hydrogen-rich syngas production explored.

$>$ Effects of various process parameters on hydrogenrich syngas formation via conventionally- and microwave-heated gasification processes described. $>$ Co-feeding configurations, ideal for hydrogen-rich syngas production via microwave heating cogasification, are explained.

$>$ Knowledge gaps and future research directions in microwave-assisted gasification and co-gasification for hydrogen-rich syngas synthesis identified. $>$ The most recent achievements in hydrogen yield, concentration, and cost are discussed.

\section{GRAPHICAL ABSTRACT}

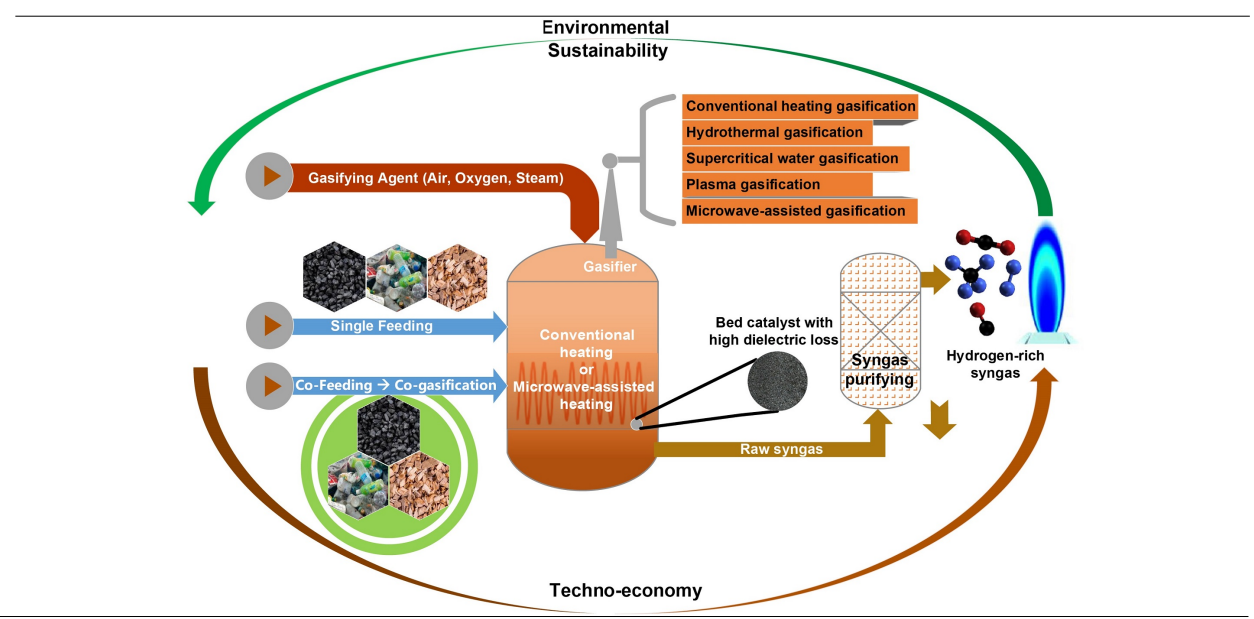

\section{ARTICLE INFO}

\section{Article history:}

Received 11 December 2021

Received in revised form 17 February 2022

Accepted 19 February 2022

Available online 1 March 2022

\section{Keywords:}

Hydrogen-rich syngas

Co-gasification

Hydrothermal gasification

Supercritical water gasification

Plasma gasification

Microwave-assisted gasification

\begin{abstract}
Co-gasification contributes significantly to the generation of hydrogen-rich syngas since it not only addresses the issue of feedstock variation but also has synergistic benefits. In this article, recent research on hydrogen concentration and yield, tar content, gasification efficiency, and carbon conversion efficiency is explored systematically. In feedstocks with high water content, steam gasification and supercritical hydrothermal gasification technologies are ideal for producing hydrogen at a concentration of $57 \%$, which can be increased to $82.9 \%$ using purification technology. Carbonized coals, chars, and cokes have high microwave absorption when used as feedstocks. Moreover, coconut activated carbon contains elements that provide a high $\tan \delta$ value and are worthy of further development as feedstocks, adsorbents or catalysts. Meanwhile, the $\mathrm{FeSO}_{4}$ catalyst has the greatest capacity for storing microwave energy and producing dielectric losses; therefore, it can serve as both a catalyst and microwave absorber. Although microwave heating is preferable to conventional heating, the amount of hydrogen it generates remains modest, at $60 \%$ and $32.75 \%$ in single-feeding and co-feeding modes, respectively. The heating value of syngas produced using microwaves is $17.44 \mathrm{MJ} / \mathrm{m}^{3}$, much more than that produced via conventional heating. Thus, despite a lack of research on hydrogen-rich syngas generation based on co-gasification and microwave heating, such techniques have the potential to be developed at both laboratory and industrial scales. In addition, the dielectric characteristics of feedstocks, beds, adsorbents, and catalysts must be further investigated to optimize the performance of microwave heating processes.
\end{abstract}

(C) 2022 BRTeam. All rights reserved.

* Corresponding author at: Tel.: +62 8170621951

E-mail address: suyitno@uns.ac.id

Please cite this article as: Rosyadi I., Suyitno S., Ilyas A.X., Faishal A., Budiono A., Yusuf M. Producing hydrogen-rich syngas via microwave heating and co-gasification: a systematic review. Biofuel Research Journal 33 (2022) 1573-1591. DOI: 10.18331/BRJ2022.9.1.4 


\section{Contents}

1. Introduction.

2. Research methodology

2.1. Portfolio articles.

2.2. Data synthesis and analysis.

3. Bibliometric analysis.

4. Microwave-assisted gasification and co-gasification.

4.1. Effect of feedstock and blending ratio on hydrogen-rich syngas

4.2. Effects of gasification agents and equivalence ratio on hydrogen-rich syngas

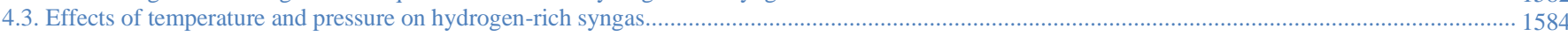

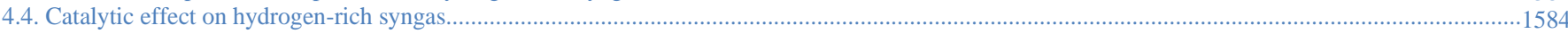

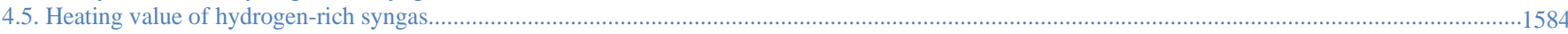

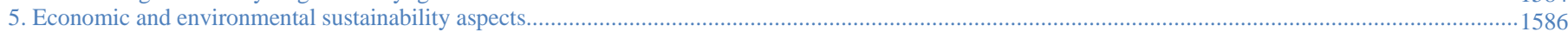

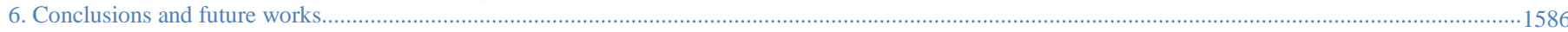

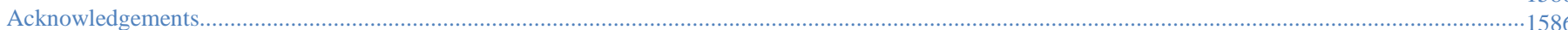

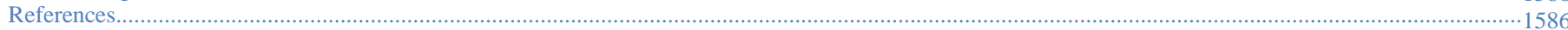

\section{Introduction}

Future hydrogen consumption is estimated to reach $2.3 \mathrm{Gt} / \mathrm{yr}$ in industries that include synthetic chemistry, transportation, buildings, heating, and power storage. Hydrogen can decarbonize approximately $18 \%$ of energy-related industries and complement renewable electricity to serve as an essential component of a $100 \%$ renewable energy society (Oliveira et al., 2021). At the moment, more than $98 \%$ of hydrogen is generated from fossil fuels, namely, $76 \%$ from the wet reforming of hydrocarbons and $22 \%$ via coal gasification (Lepage et al., 2021). The continuous increases in energy demand, environmental concerns and resource depletion, and fluctuating fossil fuel prices (Okolie et al., 2020a), have generated interest in producing hydrogen from sustainable energy sources such as biomass, municipal solid waste (MSW), and sewage sludge.

Numerous processes have been developed for hydrogen production from renewable feedstocks, including electrolysis, pyrolysis, hydrothermal, gasification, and reforming. Currently, the primary technique for hydrogen generation is steam reforming. However, this method has several problems, including thermal inefficiency, mechanical and maintenance concerns, difficult management, and significant capital investment requirements. There are two primary techniques for producing hydrogen from solid fuels: thermochemical and biological. Pyrolysis, liquefaction, wet reforming, gasification, and supercritical water gasification (SCWG) are plausible thermochemical routes (Shahbaz et al., 2020a). The main advantage of pyrolysis and gasification technologies is the capacity to treat lower-quality raw materials under highefficiency settings (Cormos, 2013). However, both pyrolysis and gasification frequently require external heat, and the hydrogen produced contains various impurities, such as tar, coke, $\mathrm{CH}_{4}, \mathrm{CO}_{2}, \mathrm{~N}_{2}, \mathrm{O}_{2}, \mathrm{CO}, \mathrm{NH}_{3}$, and $\mathrm{HCl}$. As a result, technologies for producing hydrogen-rich syngas from solid fuels and MSW are critical for the future. Without neglecting the importance of other factors, there are at least four areas with the potential for continued development: technology, raw resources, economics, and the environment.

Several technologies and methods for converting biomass to syngas with a high concentration of hydrogen have been thoroughly studied. Biomass can be converted to hydrogen chemically by examining the effects of reaction factors such as conversion techniques, influencing variables, and catalyst types on hydrogen generation and carbon conversion efficiency (CCE) (Li et al., 2019). The CCE and hydrogen production are influenced by feedstocks, reactors, temperatures, catalysts and agent/feedstock ratios. Natural catalysts present in ash, particularly alkaline earth metal compounds, facilitate CCE and boost tar cracking to create hydrogen from biomass via environmentally friendly routes. Metal catalysts and oxides increase hydrogen production by steam-reforming techniques and C-O and C-C bond splitting (Li et al., 2019). Several other studies have examined the synthesis of hydrogen from biomass by thermochemical processes, most notably pyrolysis and gasification (Pandey et al., 2019). Meanwhile, CO-rich syngas that can particularly be obtained using $\mathrm{CO}_{2}$ as gasifying agent has been evaluated (Chan et al., 2021). Hydrogen-rich syngas production from biogenic, polymeric, and petroleum wastes has been extensively studied using sub- and super-critical hydrothermal gasification. This method is particularly well-suited to raw materials with high water contents because it eliminates the need for drying and dewatering, thereby lowering operating costs (Okolie et al., 2020a). Along with the conversion technology, hydrogen-rich syngas can be generated by integrating equipment and purification technologies such as membranes. These are widely available at lower operating costs than other gas-purifying technologies but still require further development in terms of selectivity and permeability and to minimize constraints to achieve practical feasibility (Shahbaz et al., 2020a). Additional options include the use of a gasifier in conjunction with reforming (Demirbas, 2016; Shahabuddin et al., 2020) or the co-gasification of glycerol and lignocellulosic biomass (ĐurišićMladenović et al., 2016).

Although the potential for raw material usage is considerable, biomass is available in various forms, which imposes limits on its homogenous and steady supply. To compensate for variations in raw materials, a co-feeding technique has been introduced for use with pyrolysis, gasification or hydrothermal processes that combine several types of feedstocks. A cogasification review addressed syngas produced by the co-feeding of petroleum coke and coal (Wang et al., 2021), coal and biomass (Valero and Usón, 2006; Emami-Taba et al., 2012 and 2013; Mallick et al., 2017; Xiang et al., 2018; Wei et al., 2019), biomass and plastic, biomass and sewage sludge, plastic blends (Shahbaz et al., 2020b), or biomass and waste (Ramos et al., 2018). Inayat et al. studied the effects of different feedstocks and mixing ratios on the quality of syngas (Inayat et al., 2019). It was observed that while the routes from unusual solid fuels to hydrogen-rich syngas have been extensively explored, they have seldom been reviewed from the perspective of microwave heating. Microwave gasification has been studied, emphasizing catalyst roles, syngas generation, CCE elimination, and suggestions for ideal settings (Arpia et al., 2022).

Thus, the present study's objectives were to 1) provide a detailed bibliographic analysis of gasification and co-gasification technology for producing hydrogen-rich syngas and 2) compare the use of conventional and microwave heating in syngas production according to studies published between 2012 and 2022. Thus, this study is intended to provide an understanding of current knowledge to direct future research, particularly regarding technology for hydrogen production from gasification and cogasification utilizing conventional or microwave heating. During the systematic review, a bibliographic coupling analysis and text mining analysis were performed using VOSviewer software. A time overlay and clustering visualization of keywords, countries and authors making significant contributions to the field of hydrogen-rich syngas from gasification are systematically reviewed in this study. Table 1 compares the current review's findings on many elements of hydrogen-rich syngas production from gasification to those of earlier review articles published between 2012 and 2022. To our knowledge, there are relatively few studies of hydrogen-rich syngas generation that incorporate the notion of cofeeding with microwave heaters.

The following ten groups of research questions explain why in-depth investigations should be conducted:

$>$ What function does microwave technology play in gasification and co-gasification? 
Table 1.

Comparison of the present review with previously published reviews on hydrogen-rich syngas production through gasification between 2012 and 2022

\begin{tabular}{|c|c|c|c|c|c|c|c|c|c|c|c|c|}
\hline \multicolumn{2}{|c|}{ Feedstocks } & \multicolumn{2}{|c|}{ Heating } & \multicolumn{5}{|c|}{ Gasifying agent } & \multirow[b]{2}{*}{ Catalysts } & \multirow[b]{2}{*}{$\begin{array}{l}\text { Hydrogen- } \\
\text { rich syngas }\end{array}$} & \multirow[b]{2}{*}{$\begin{array}{c}\text { Economic } \\
\text { analysis }\end{array}$} & \multirow[b]{2}{*}{ Ref. } \\
\hline $\begin{array}{c}\text { Single } \\
\text { feedstock }\end{array}$ & $\begin{array}{c}\text { Co- } \\
\text { gasification }\end{array}$ & Conventional & Microwave & Air & Steam & $\begin{array}{l}\text { Sub or super- } \\
\text { critical steam }\end{array}$ & $\mathrm{CO}_{2}$ & Combination & & & & \\
\hline$\sqrt{ }$ & $x$ & $x$ & $\sqrt{ }$ & $\sqrt{ }$ & $\sqrt{ }$ & $x$ & $\sqrt{ }$ & $\sqrt{ }$ & $\sqrt{ }$ & $\sqrt{ }$ & $x$ & Arpia et al. (2022) \\
\hline$\sqrt{ }$ & $x$ & $x$ & $\sqrt{ }$ & $\times$ & $\times$ & $x$ & $\sqrt{ }$ & $\times$ & $\times$ & $\times$ & $\times$ & Zamri et al. (2021) \\
\hline$\sqrt{ }$ & $\sqrt{ }$ & $\sqrt{ }$ & $\sqrt{ }$ & $\times$ & $\times$ & $\times$ & $\sqrt{ }$ & $\times$ & $\sqrt{ }$ & $\times$ & $\times$ & Chan et al. (2021) \\
\hline$\sqrt{ }$ & $\sqrt{ }$ & $\sqrt{ }$ & $x$ & $\sqrt{ }$ & $\sqrt{ }$ & $\times$ & $\times$ & $x$ & $\sqrt{ }$ & $\sqrt{ }$ & $x$ & Emami-Taba et al. (2013) \\
\hline$\sqrt{ }$ & $\times$ & $\sqrt{ }$ & $\sqrt{ }$ & $\sqrt{ }$ & $\sqrt{ }$ & $\times$ & $\times$ & $x$ & $\times$ & $\sqrt{ }$ & $x$ & Ho et al. (2017) \\
\hline$\sqrt{ }$ & $\sqrt{ }$ & $\sqrt{ }$ & $\times$ & $\sqrt{ }$ & $\sqrt{ }$ & $\times$ & $\times$ & $\times$ & $\sqrt{ }$ & $\sqrt{ }$ & $\times$ & Inayat et al. (2019) \\
\hline$\sqrt{ }$ & $x$ & $\sqrt{ }$ & $\times$ & $\sqrt{ }$ & $\sqrt{ }$ & $\times$ & $\times$ & $\times$ & $\sqrt{ }$ & $\sqrt{ }$ & $\times$ & Lepage et al. (2021) \\
\hline$\sqrt{ }$ & $\times$ & $\sqrt{ }$ & $x$ & $\times$ & $\times$ & $\sqrt{ }$ & $x$ & $x$ & $\sqrt{ }$ & $\sqrt{ }$ & $x$ & Okolie et al. (2020a) \\
\hline$\sqrt{ }$ & $x$ & $\sqrt{ }$ & $\sqrt{ }$ & $\sqrt{ }$ & $\sqrt{ }$ & $x$ & $x$ & $x$ & $\sqrt{ }$ & $\sqrt{ }$ & $\sqrt{ }$ & Pandey et al. (2019) \\
\hline$\sqrt{ }$ & $\sqrt{ }$ & $\sqrt{ }$ & $x$ & $\sqrt{ }$ & $\sqrt{ }$ & $\times$ & $x$ & $\sqrt{ }$ & $\sqrt{ }$ & $\sqrt{ }$ & $x$ & Ramos et al. (2018) \\
\hline$\sqrt{ }$ & $\sqrt{ }$ & $\sqrt{ }$ & $x$ & $\sqrt{ }$ & $\sqrt{ }$ & $x$ & $x$ & $x$ & $\sqrt{ }$ & $\sqrt{ }$ & $x$ & Shahbaz et al. (2020b) \\
\hline$\sqrt{ }$ & $x$ & $\sqrt{ }$ & $\times$ & $\sqrt{ }$ & $\sqrt{ }$ & $\times$ & $\times$ & $\sqrt{ }$ & $\sqrt{ }$ & $\sqrt{ }$ & $\times$ & Shahbaz et al. (2020a) \\
\hline$\sqrt{ }$ & $\times$ & $\sqrt{ }$ & $\sqrt{ }$ & $\sqrt{ }$ & $\sqrt{ }$ & $x$ & $x$ & $x$ & $\sqrt{ }$ & $\sqrt{ }$ & $x$ & State et al. (2019) \\
\hline$\sqrt{ }$ & $\sqrt{ }$ & $\sqrt{ }$ & $\times$ & $\sqrt{ }$ & $\sqrt{ }$ & $\times$ & $\times$ & $\times$ & $\sqrt{ }$ & $\sqrt{ }$ & $\times$ & Emami-Taba et al. (2012) \\
\hline$\sqrt{ }$ & $\sqrt{ }$ & $\sqrt{ }$ & $x$ & $\sqrt{ }$ & $\sqrt{ }$ & $\times$ & $\times$ & $\sqrt{ }$ & $\sqrt{ }$ & $\sqrt{ }$ & $x$ & Wang et al. (2021) \\
\hline$\sqrt{ }$ & $x$ & $\sqrt{ }$ & $\sqrt{ }$ & $\sqrt{ }$ & $x$ & $x$ & $x$ & $x$ & $\sqrt{ }$ & $x$ & $x$ & Zhang et al. (2020a) \\
\hline$\sqrt{ }$ & $\sqrt{ }$ & $\sqrt{ }$ & $\sqrt{ }$ & $\sqrt{ }$ & $\sqrt{ }$ & $\sqrt{ }$ & $\sqrt{ }$ & $\sqrt{ }$ & $\sqrt{ }$ & $\sqrt{ }$ & $\sqrt{ }$ & This review \\
\hline
\end{tabular}

$\sqrt{ }$ : Included

$x$ : Not included

$>$ What factors must be addressed in order to maximize the effect of microwave heating on gasification and co-gasification?

What effect do feedstocks have on the hydrogen content of syngas?

$>$ Which feedstocks have been investigated in terms of gasification and co-gasification using microwave or conventional heating to produce hydrogen-rich syngas?

$>$ How can we identify co-feeding configurations that are ideal for hydrogen-rich syngas produced by microwave-heated co-gasification?

Is there a synergistic effect when co-gasification is used?

$>$ What effect does the gasification agent have on the hydrogen content of syngas?

$>$ Which gasification agents have been investigated in connection to gasification and co-gasification using microwave or conventional heating to produce hydrogen-rich syngas?

$>$ What function do catalysts play in the gasification and co-gasification of hydrogen-rich syngas under conventional and microwave heating?

$>$ What research gaps remain, and do they need further investigation to guide future studies?

\section{Research methodology}

\subsection{Portfolio articles}

The PRISMA method was used in this systematic review (Moher et al., 2009), as shown in Figure 1 . The initial step was to identify a research topic on hydrogen-rich syngas by searching Google Scholar, which generated 2,610 articles. If only publications published after 2012 are included in searches, the number of research articles on hydrogen-rich syngas themes drops to 1,510 on Google Scholar and 664 on ScienceDirect.

\subsection{Data synthesis and analysis}

A total of 76 high-impact publications were meticulously compiled and analyzed in accordance with the study's objectives. Some secondary data were retained, particularly those published before 2012 that were relevant to the issue under discussion, bringing the total to 140 articles. To begin, an overview of hydrogen-rich gasification and co-gasification is provided. Second, focus research was undertaken on microwave gasification and co-gasification to determine their current research status, including any shortcomings. In this second emphasis, data on the major factors affecting the synthesis of hydrogen-rich syngas via microwave and conventional heating were gathered and analyzed. Third, the function and method of co-gasification for generating hydrogen-rich syngas via microwave heating was explored and analyzed. This procedure yielded a summary of the fundamentals of microwave co-gasification, the main findings, many factors affecting hydrogen-rich syngas, and critical information on microwave cogasification.

\section{Bibliometric Analysis}

Figure 2 depicts an analysis of keyword co-occurrences conducted using VOSviewer software. There were 402 thresholds of 11,288 keywords and four clusters with a minimum occurrence of 20. Biomass had the most occurrences (842), followed by 15 additional keywords in the following order: gasification, pyrolysis, hydrogen, hydrogen generation, catalysts, carbon dioxide, synthesis gas, tar, steam reforming, carbon, steam, biomass gasification, chemical reactors, fluidized beds, and temperature. It has been observed that biomass feedstocks are used more frequently in the production of hydrogen-rich syngas. Steam is the most extensively examined gasification agent. Carbon dioxide, catalyst, and tar were also among the issues that received much attention from researchers between 2012 and 2022. Meanwhile, the numbers of occurrences of hydrogen-rich gas, microwaves, co-gasification, and economy were 56, 86, 61, and 50, respectively. Moreover, there were 504, 142, 831, 61, 22, 81, 15, 86, and 13 occurrences of hydrogen, syngas, gasification, co-gasification, hydrothermal gasification, supercritical water gasification, plasma gasification, microwave, and dielectric, respectively.

The sizes and colors of the keywords in Figure 2 correspond to their occurrence and clusters encountered. The wider the circle, the more common the occurrence. Meanwhile, the tighter the link between the keywords depicted in the figure, the closer they are in relation to each other. To better understand the investigation's quantitative findings, a qualitative content analysis using VOSviewer based on four clusters was done. Cluster 1 is red and is dominated by research on exergy, energy efficiency, fossil 


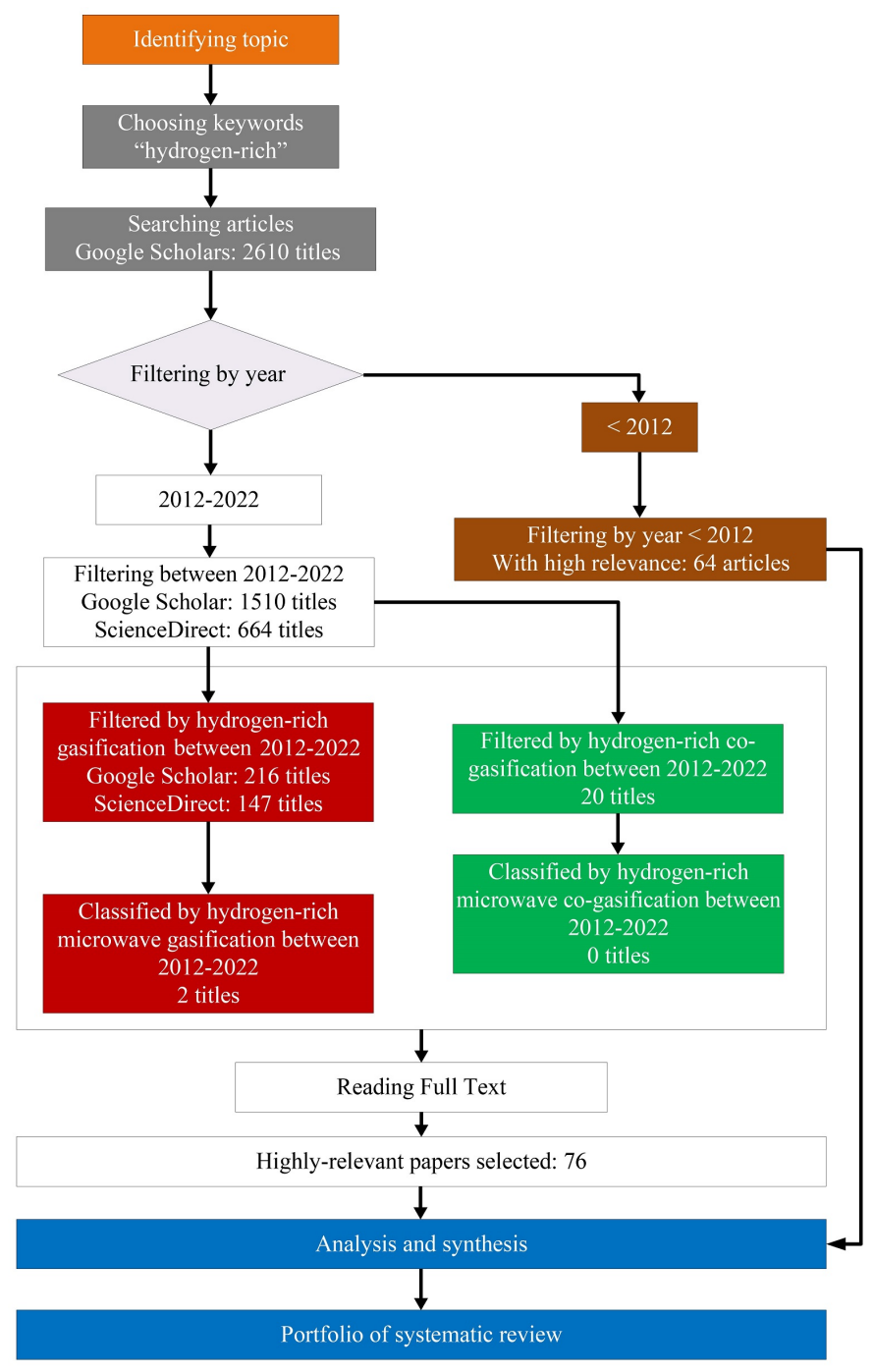

Fig. 1. The PRISMA method used in this systematic review.

fuels, investment, supercritical water, raw materials, and life cycles, as determined by text mining analysis. Cluster 1's keyword distribution appears to be more spread out than those of the other clusters. Cluster 2 is green, with a

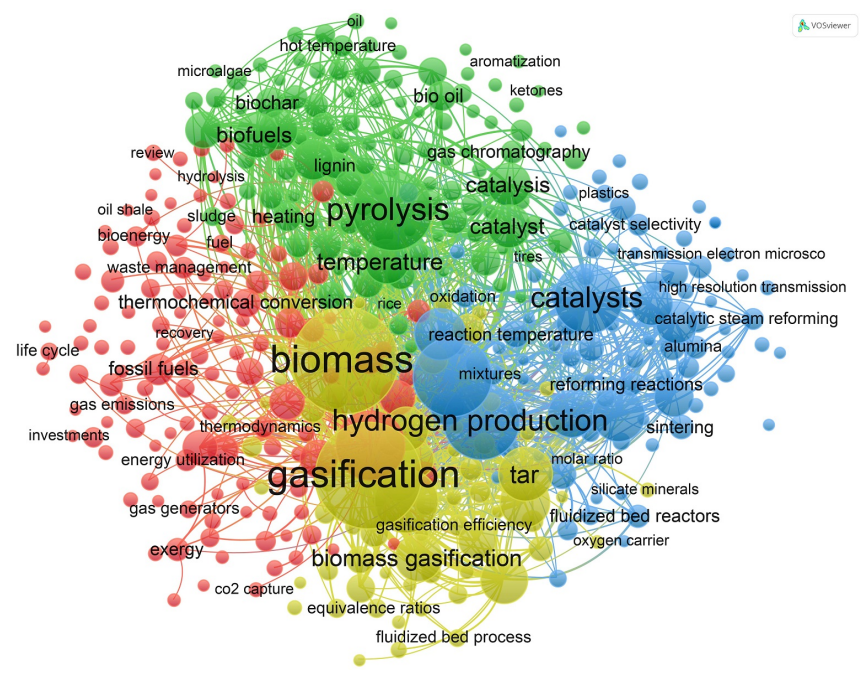

Fig. 2. VOSviewer co-occurrence map combined with unit analysis identifying keywords in articles related to gasification and hydrogen-rich.

higher frequency of occurrence than cluster 1 , and is associated with studies on pyrolysis, catalysis, bio-oil, and biofuels. Additionally, Cluster 2 demonstrates that bio-oils and biofuels are extensively explored in relation to the catalytic pyrolysis process. Cluster 3 (blue) also includes a high prevalence of issues related to hydrogen production and catalyst research. Cluster 4 (yellow) has a high number of references to biomass, gasification, and steam gasification.

Figure 3 depicts a chronological overlay of keywords from publications with the keywords gasification and hydrogen-rich. The colors in Figure 3 represent the average date of publication. Blue represents earlier publications, whereas yellow represents more current publications. Yellow phrases, such as investment, economy, life cycle, and sustainable development, with an average date of publication of 2017, indicate that this research topic is relatively new and under-researched. The two primary keywords employed in this review, microwaves and co-gasification, had average publication dates of 2016. It can also be noted that the term microwaves is explored together with biofuels, heating, bio-oil, pyrolysis, catalysts, biomass, energy efficiency, carbon dioxide, and gas synthesis. Meanwhile, co-gasification is extensively researched together with gasification, carbon dioxide, biomass, coal, and hydrogen. It may also be noted from Figure 3 that microwaves and co-gasification are still used and studied separately.

Time overlay visualization of countries that published hydrogen-richand gasification-related papers between 2012 and 2022 is shown

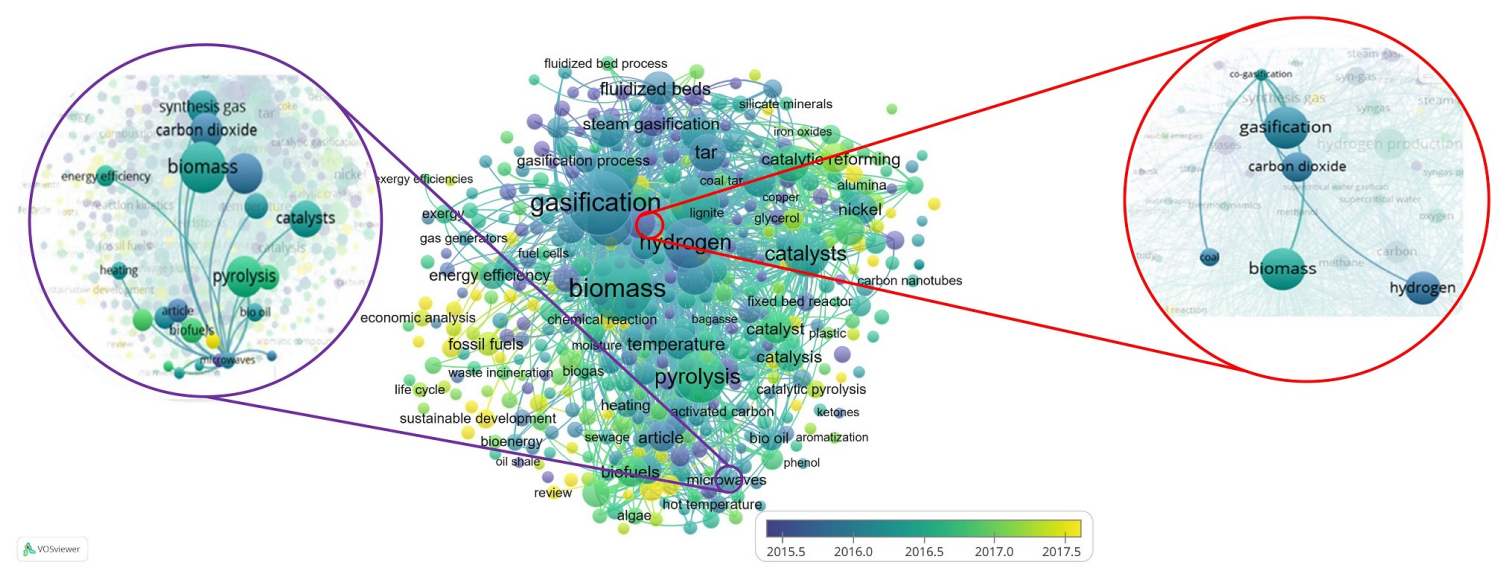

Fig. 3. VOSviewer time overlay map combined with unit analysis identifying terms in articles related to gasification and hydrogen-rich.

Please cite this article as: Rosyadi I., Suyitno S., Ilyas A.X., Faishal A., Budiono A., Yusuf M. Producing hydrogen-rich syngas via microwave heating and co-gasification: a systematic review. Biofuel Research Journal 33 (2022) 1573-1591. DOI: 10.18331/BRJ2022.9.1.4 
in Figure 4. China appears to have the most publications, followed by India, Malaysia, Iran, Canada, the United States, Germany, and South Korea. With an average publication date of 2019, Canada, Saudi Arabia, and Qatar are the nations that are pursuing intense gasification and hydrogen-rich research.

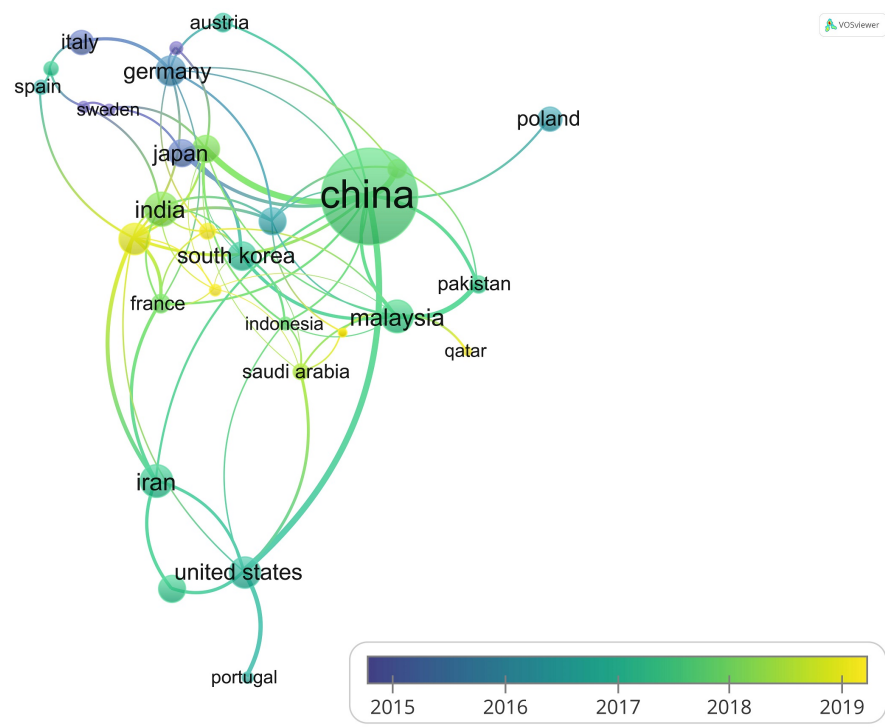

Fig. 4. A time overlay visualization of the nations where the corresponding authors of relevant publications reside.

Figures 5 and 6 show some of the prolific writers. There is no discernible relationship between the number of papers published by the author and the number of citations. Jin (20 papers), Chen (18 papers), and Wang (15 papers) are the three writers with the most documents. The three writers with the most citations are Kozinski (632 citations), Nanda (632 citations), and Dalai (615 citations).

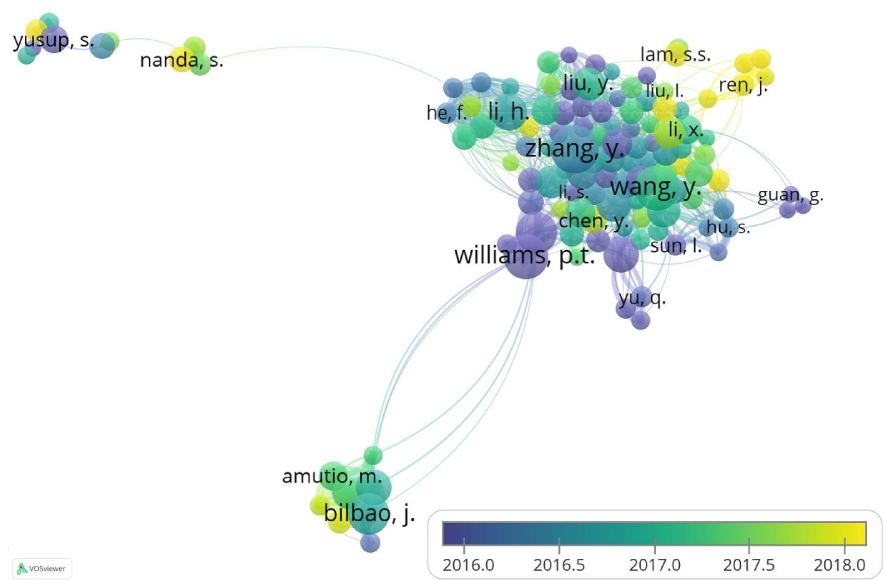

Fig. 5. Well-known authors in the domains of hydrogen-rich and gasification.

As illustrated in Table 2, the 15 most influential publications (based on the number of times they were cited and their formed linkages with breakthrough works) depict the progressive growth in hydrogen-rich gasification research from 2012 to 2022. The most citation-dense papers were published in the journals Renewable and Sustainable Energy Reviews (H-index 295, Q1), Water Research (H-index 303, Q1), Energy Conversion and Management (H-index 192, Q1), Applied Energy (H-index 212, Q1), Fuel (H-index 213, Q1),

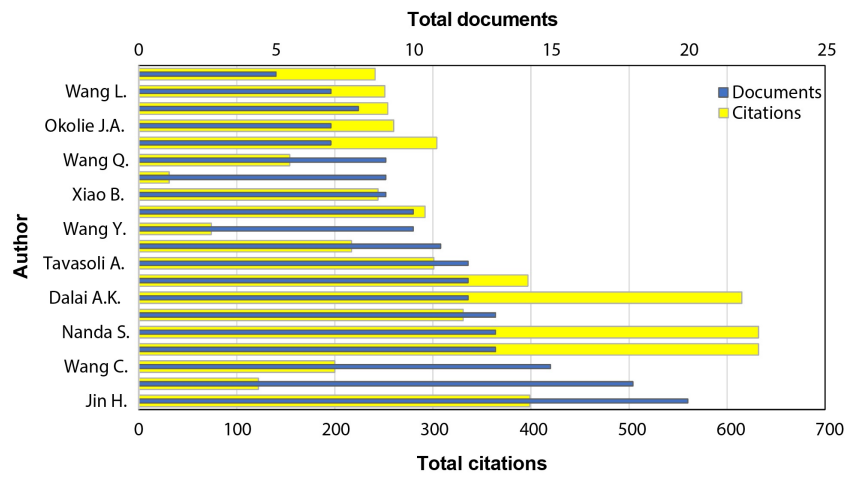

Fig. 6. The 15 most productive authors in the domains of hydrogen-rich and gasification.

International Journal of Hydrogen Energy (H-index 215, Q1), Biomass and Bioenergy (H-index 180, Q1), and Sustainable Energy and Fuels (H-index 191, Q1). Between 2012 and 2017, these publications generated over 100 citations. Topics such as hydrogen yields, coal gasification, fluidized beds, tar, and carbonization are highlighted in blue-green on the 15 mostreferenced publications from the previous decade in Figure 7. New issues, such as synthesis gas, catalysts, hydrogen generation, supercritical water, thermochemistry, and gasification efficiency, are highlighted in yellow.

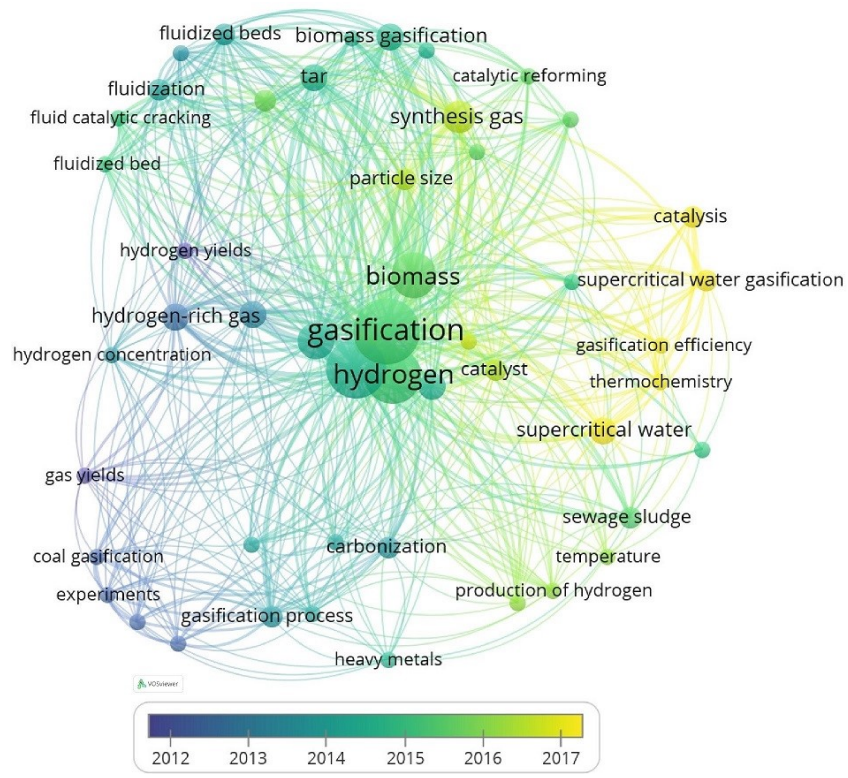

Fig. 7. An overlay map of keywords found in the top- 15 most-cited publications.

As seen in Figure 8, the 216 papers found with Google Scholar may then be classified using the primary keywords hydrogen-rich, gasification, cogasification, and microwave published after 2012. The vast majority of researchers $(>54 \%)$ are interested in microwave gasification, whereas just a few $(1 \%)$ are interested in microwave co-gasification. There are only two articles containing the keywords microwave, gasification, and hydrogenrich. In addition, there are no articles containing the keywords microwave, co-gasification, and hydrogen-rich. In publications with a high impact, 76 were gathered and utilized as a portfolio in this study's systematic review, which is anticipated to offer a full grasp of the study's breadth and uncover knowledge gaps (Xiao and Watson, 2019). Figure 9 illustrates the word connections that were often referenced in titles, abstracts, and keywords in 
Table 2.

The data for the most cited articles in the field of hydrogen-rich syngas generated by gasification.

\begin{tabular}{|c|c|c|c|c|c|c|}
\hline No & Authors & Title & Journal & Year & Number of citations & Ref. \\
\hline 1 & Udomsirichakorn, J., Salam, P.A. & $\begin{array}{l}\text { Review of hydrogen-enriched gas production from } \\
\text { steam gasification of biomass: The prospect of } \mathrm{CaO} \text { - } \\
\text { based chemical looping gasification }\end{array}$ & $\begin{array}{l}\text { Renewable and Sustainable } \\
\text { Energy Reviews } \\
\text { 30, pp. } 565-579\end{array}$ & 2014 & 197 & $\begin{array}{l}\text { Udomsirichakorn and } \\
\text { Salam (2014) }\end{array}$ \\
\hline 2 & $\begin{array}{l}\text { Qian, L., Wang, S., Xu, D., Guo, } \\
\text { Y., Tang, X., Wang, L. }\end{array}$ & $\begin{array}{l}\text { Treatment of municipal sewage sludge in supercritical } \\
\text { water: A review }\end{array}$ & $\begin{array}{l}\text { Water Research 89, pp. 118- } \\
131\end{array}$ & 2016 & 166 & Qian et al. (2016) \\
\hline 3 & $\begin{array}{l}\text { He, C., Chen, C.-L., Giannis, A., Yang, } \\
\text { Y., Wang, J.Y. }\end{array}$ & $\begin{array}{l}\text { Hydrothermal gasification of sewage sludge and model } \\
\text { compounds for renewable hydrogen production: A } \\
\text { review }\end{array}$ & $\begin{array}{l}\text { Renewable and Sustainable } \\
\text { Energy Reviews } \\
\text { 39, pp. } 1127-1142\end{array}$ & 2014 & 146 & He et al. (2014) \\
\hline 4 & $\begin{array}{l}\text { Nanda, S., Isen, J., Dalai, } \\
\text { A.K., Kozinski, J.A. }\end{array}$ & $\begin{array}{l}\text { Gasification of fruit wastes and agro-food residues in } \\
\text { supercritical water }\end{array}$ & $\begin{array}{c}\text { Energy Conversion and } \\
\text { Management } \\
\text { 110, pp. } 296-306\end{array}$ & 2016 & 141 & Nanda et al. (2016) \\
\hline 5 & Al-Rahbi, A.S., Williams, P.T. & $\begin{array}{l}\text { Hydrogen-rich syngas production and tar removal from } \\
\text { biomass gasification using sacrificial tyre pyrolysis } \\
\text { char }\end{array}$ & $\begin{array}{l}\text { Applied Energy } \\
190 \text {, pp. 501-509 }\end{array}$ & 2017 & 120 & $\begin{array}{l}\text { Al-Rahbi and Williams } \\
\text { (2017) }\end{array}$ \\
\hline 6 & $\begin{array}{l}\text { Stańczyk, K., Kapusta, K., Wiatowski, } \\
\text { M., Świdrowski J., Smoliński A., } \\
\text { Rogut, J., Kotyrba, A. }\end{array}$ & $\begin{array}{l}\text { Experimental simulation of hard coal underground } \\
\text { gasification for hydrogen production }\end{array}$ & $\begin{array}{l}\text { Fuel } \\
91(1), \text { pp. } 40-50\end{array}$ & 2012 & 104 & Stańczyk et al. (2012) \\
\hline 7 & $\begin{array}{l}\text { Fremaux, S., Beheshti, S.-M., Ghassemi, } \\
\text { H., Shahsavan-Markadeh, R. }\end{array}$ & $\begin{array}{l}\text { An experimental study on hydrogen-rich gas production } \\
\text { via steam gasification of biomass in a research-scale } \\
\text { fluidized bed }\end{array}$ & $\begin{array}{l}\text { Energy Conversion and } \\
\text { Management } \\
91, \text { pp. } 427-432\end{array}$ & 2015 & 102 & Fremaux et al. (2015) \\
\hline 8 & $\begin{array}{l}\text { Jingbo Wang, Gong Cheng, Yanli You, } \\
\text { BoXiao, Shiming Liu, Piwen He, } \\
\text { DabinGuo, Xianjun Guo, Guijuan } \\
\text { Zhang }\end{array}$ & $\begin{array}{l}\text { Hydrogen-rich gas production by steam gasification of } \\
\text { municipal solid waste (MSW) using NiO supported on } \\
\text { modified dolomite }\end{array}$ & $\begin{array}{l}\text { International Journal of } \\
\text { Hydrogen Energy, } 37 \text { (8), } \\
\text { April 2012, pp. 6503-6510 }\end{array}$ & 2012 & 102 & Wang et al. (2012) \\
\hline 9 & Song, T., Wu, J., Shen, L., Xiao, J. & $\begin{array}{l}\text { Experimental investigation on hydrogen production } \\
\text { from biomass gasification in interconnected fluidized } \\
\text { beds }\end{array}$ & $\begin{array}{l}\text { Biomass and Bioenergy } \\
\text { 36, pp. } 258-267\end{array}$ & 2012 & 102 & Song et al. (2012) \\
\hline 10 & $\begin{array}{l}\text { Okolie, J.A., Rana, R., Nanda, S., Dalai, } \\
\text { A.K., Kozinski, J.A. }\end{array}$ & $\begin{array}{l}\text { Supercritical water gasification of biomass: A state-of- } \\
\text { the-art review of process parameters, reaction } \\
\text { mechanisms and catalysis }\end{array}$ & $\begin{array}{l}\text { Sustainable Energy and Fuels } \\
\text { 3(3), pp. } 578-598\end{array}$ & 2019 & 97 & Okolie et al. (2019) \\
\hline 11 & $\begin{array}{l}\text { Beheshti, S.M., Ghassemi, } \\
\text { H., Shahsavan-Markadeh, R. }\end{array}$ & $\begin{array}{l}\text { Process simulation of biomass gasification in a } \\
\text { bubbling fluidized bed reactor }\end{array}$ & $\begin{array}{l}\text { Energy Conversion and } \\
\text { Management } \\
\text { 94, pp. 345-352 }\end{array}$ & 2015 & 97 & Beheshti et al. (2015) \\
\hline 12 & $\begin{array}{l}\text { Kapusta, K., Stańczyk, K., Wiatowski, } \\
\text { M., Chećko, J. }\end{array}$ & $\begin{array}{l}\text { Environmental aspects of a field-scale underground } \\
\text { coal gasification trial in a shallow coal seam at the } \\
\text { Experimental Mine Barbara in Poland }\end{array}$ & $\begin{array}{c}\text { Fuel } \\
113 \text {, pp. } 196-208\end{array}$ & 2013 & 88 & Kapusta et al. (2013) \\
\hline 13 & $\begin{array}{l}\text { Gai, C., Guo, Y., Liu, T., Peng, N., Liu, } \\
\text { Z. }\end{array}$ & $\begin{array}{l}\text { Hydrogen-rich gas production by steam gasification of } \\
\text { hydrochar derived from sewage sludge }\end{array}$ & $\begin{array}{l}\text { International Journal of } \\
\text { Hydrogen Energy } \\
\text { 41(5), pp. 3363-3372 }\end{array}$ & 2016 & 86 & Gai et al. (2016) \\
\hline 14 & $\begin{array}{l}\text { Nanda, S., Rana, R., Hunter, H.N., Fang } \\
\text { Z., Dalai, A.K., Kozinski, J.A. }\end{array}$ & $\begin{array}{l}\text { Hydrothermal catalytic processing of waste cooking oil } \\
\text { for hydrogen-rich syngas production }\end{array}$ & $\begin{array}{l}\text { Chemical Engineering Science } \\
\text { pp. } 935-945\end{array}$ & 2019 & 80 & Nanda et al. (2019) \\
\hline 15 & $\begin{array}{l}\text { Hamad, M.A., Radwan, A.M., Heggo, } \\
\text { D.A., Moustafa, T. }\end{array}$ & $\begin{array}{l}\text { Hydrogen rich gas production from catalytic } \\
\text { gasification of biomass }\end{array}$ & $\begin{array}{l}\text { Renewable Energy } \\
\text { 85, pp. } 1290-1300\end{array}$ & 2016 & 78 & Hamad et al. (2016) \\
\hline
\end{tabular}

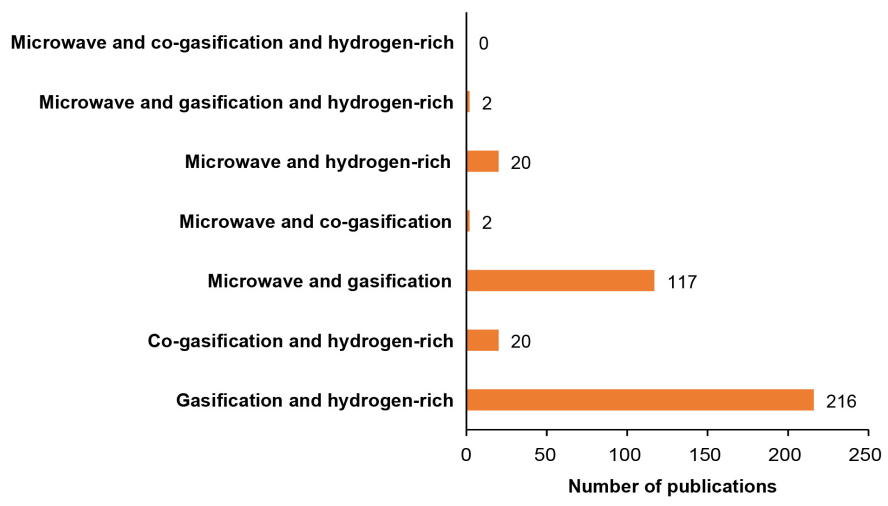

Fig. 8. Classification of research interest using the primary keywords hydrogen-rich, gasification, co-gasification, and microwave.

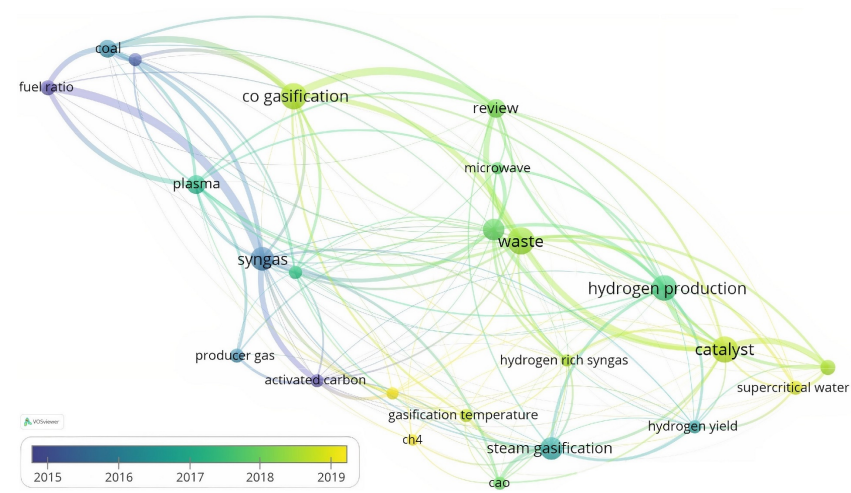

Fig. 9. The word connections that were often referenced in titles, abstracts, and keywords. 
the 76 publications. As can be seen, syngas, co-gasification, waste, catalyst, hydrogen production, and steam gasification were more often referenced while fewer references were given to coal, plasma, activated carbon, $\mathrm{CH}_{4}, \mathrm{CaO}$, hydrogen yield, and supercritical water gasification. In the meanwhile, greenyellow keywords such as co-gasification, catalyst, hydrogen-rich syngas, microwave, and supercritical water gasification have been researched in recent years.

\section{Microwave-assisted gasification and co-gasification}

Co-gasification is a method of producing synthetic gas from materials or fuels. $\mathrm{H}_{2}, \mathrm{CO}, \mathrm{CO}_{2}$, and $\mathrm{N}_{2}$ are the major mass fractions of syngas generated by this process. This is accomplished by heating feedstocks to temperatures $>700$ ${ }^{\circ} \mathrm{C}$ and regulating the oxygen and/or steam quantity present in the reaction. Syngas comprises a variety of components, most notably hydrogen, and the amount of gas produced is determined by heat, which can be internal or external in nature.

Internal heating is generated by the exothermic reaction of some gasification processes. Heating from the outside is often accomplished by using an electric heater, hot gas or hot steam. Plasma technology has also been used for heating during gasification and for tar cleaning throughout its development. Microwave heating is beginning to draw the attention of many academics and is also frequently employed in the industry due to its capacity to permeate and be absorbed by radiation-exposed materials. Compared to traditional heating technologies, such as electric or gas heaters, microwaves are capable of more rapid and uniform heating of materials (Ahmad et al., 2001). Overall, microwaves have started to be widely employed in the area of gasification due to their exceptional properties (Ke et al., 2019).

Microwaves are a form of electromagnetic radiation with relatively high frequencies of $0.3-300 \mathrm{GHz}$ (Suard et al., 1996). In practice, the most commonly used frequency is $2.45 \mathrm{GHz}$ (Hrycak et al., 2014), with wavelengths ranging from 1 to $1000 \mathrm{~mm}$ (Beneroso and Fidalgo, 2016). Microwave generators typically comprise a high-voltage source, a control unit, and a magnetron head (Hrycak et al., 2014). The magnetron head is cooled by air or water, safeguarding it against the harmful effects of reflected microwave radiation

Microwaves used in gasification have been demonstrated to increase gas output. Numerous feedstocks have been investigated for use in microwave gasification in order to generate syngas, most notably, coffee hulls (Menéndez et al., 2007), corn stover (Yoon et al., 2013a), char from oil palm shells (Lahijani et al., 2014), sewage sludge (Menéndez et al., 2005), powdered coal (Shin et al., 2013), char (Yoon and Lee, 2012; Liu et al., 2019), bio-char (Wu et al., 2015), polyethylene (Sekiguchi and Orimo, 2004), and microalgae (Hu et al., 2018b). Many studies have concentrated on syngas' heating value, composition, mass fraction, and efficiency. Although all these feedstocks demonstrate that microwave gasification is preferable to traditional heating, the feedstock types are still limited, and it is not yet known how microwaves contribute to hydrogen-rich syngas.

In microwave gasification research, various researchers have conducted evaluations of catalysts (State et al., 2019), microwave-gasification simulation models of tar reduction (Zhang et al., 2020a), hydrogen and syngas production (Arpia et al., 2022), plasma gasification-to-microwave ratios (Inayat et al., 2020), and microwave plasma (Zamri et al., 2021). Catalysts are used in-situ and ex-situ. In-situ methods are more extensively used because of their simplicity; however, the rate of inactivation is significant, and recovery is rather challenging, especially at large capacities (State et al., 2019).
In the case of microwave heating, a one- or two-dimensional model is sufficient to provide an accurate simulation. This can incorporate mass and heat transfer models and consider volume changes in the affected material (Zhang et al., 2020a). Microwave gasification principles, methodologies, relevant factors, advantages, and downsides have been studied in order to create syngas with high hydrogen concentrations (Ho et al., 2017). However, there are no studies or microwave gasification reviews on cogasification, particularly techniques capable of producing high hydrogen syngas concentrations. While microwaves have been frequently used to generate hydrogen-rich syngas, the process is not yet well understood, necessitating a search for the state of the art.

Apart from being used for homogeneous heating processes, microwaves are now being extensively studied for heating heterogeneous reactions (Hunt et al., 2013; Guler et al., 2017; Bai et al., 2018). Microwaves radiate into a solid's core in heterogeneous processes. The presence of an electric field, on the other hand, leads to the dipoles $(\delta)$ being more unidirectional with respect to the solid, as seen in Figure 10. Tan $\delta$ quantifies the microwave power attenuation in a material that results in heating (Omar et al., 2011). Solids with a low $\tan \delta$ value $(<0.1)$ have low microwave absorbance, while solids with a high $\tan \delta(>0.5)$ have a high capacity for microwave absorption (Beneroso and Fidalgo, 2016). It is critical at this step to select feedstocks with a high, medium, or low $\tan \delta$ value. Materials with a low $\tan \delta$ value should not be excluded from use in microwave heating systems because they can be driven by a high-intensity electric field.

The primary distinction between traditional and microwave heating is the manner in which heat is produced. In conventional heaters, heat is transmitted by conduction from the surface to the core, resulting in a significant temperature differential for solids with a Biot number $>0.1$. As a result, the reaction begins on the surface of the solid and progresses inwards. Microwave heating creates heat at the molecular level and starts exactly from the material's interior. Microwave radiation is absorbed by substances with a $\tan \delta>0.5$ and is converted to heat, resulting in consistent interior heating. Additionally, microwave radiation has a high rate of penetration into materials, allowing it to generate heat more quickly than traditional heating. Conventional heating and microwaves are mainly different in terms of the way heating occurs. In conventional heating, heat is transported from the solid surface to the core by conduction so that the solid with a Biot number $>0.1$ will have a considerable temperature gradient. As a result, the gasification reaction begins on the surface of the solid and gradually works inward. In microwave heating, microwave energy generates heat at the molecular level, which starts precisely from the inside of the solid. Microwave energy is absorbed by solids $(\tan \delta>0.5)$ and converted into heat, consequently producing uniform internal heating. In addition, microwave radiation also gets into solids rapidly so that it can produce heat faster than conventional heating (Xie et al., 2014). When microwaves are absorbed by the solids' interior, it generates hot spots that enhance heterogeneous reaction rates.

Heterogeneous reactions involve a gas phase and solid phase. Some heterogeneous reactions that are important in gasification include the Boudouard reaction (Eq. 1) and the water-gas reaction (Eq. 2).

$\mathrm{C}+\mathrm{CO}_{2} \leftrightarrow 2 \mathrm{CO} \quad \Delta \mathrm{H}_{298 \mathrm{~K}}=173 \mathrm{~kJ} / \mathrm{mol}$

Eq. 1

$\mathrm{C}+\mathrm{H}_{2} \mathrm{O} \leftrightarrow \mathrm{CO}+\mathrm{H}_{2} \quad \Delta \mathrm{H}_{298 \mathrm{~K}}=132 \mathrm{~kJ} / \mathrm{mol}$

Eq. 2
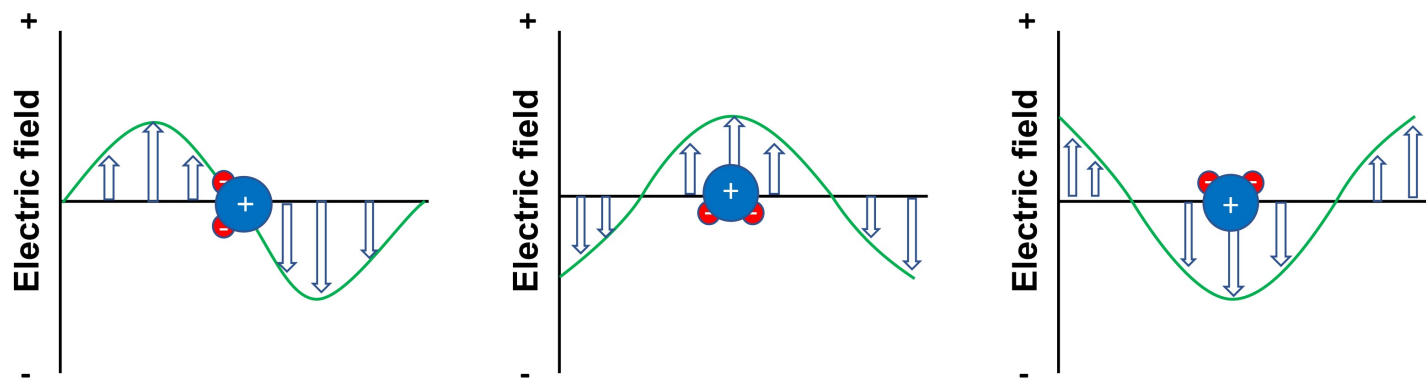

Fig. 10. Alignment of dipoles under an electric field. Adapted from Beneroso and Fidalgo (2016). 
The presence of carbon atoms causes microwave heating to be more efficient than conventional heating. Along with material carbon, the presence of potassium-containing ash contributes significantly to the heating and acceleration of homogeneous and heterogeneous processes (Domínguez et al., 2007). Additionally, potassium-containing ash functions as a catalyst. A similar phenomenon occurs when a CaO-Zr/H-ZSM-5 catalyst is employed to increase hydrogen production by up to $61 \%$ (Sun et al., 2017). This has been demonstrated to accelerate the following homogenous reaction, called dry reforming of methane (Eq. 3).

$$
\mathrm{CH}_{4}+\mathrm{CO}_{2} \leftrightarrow 2 \mathrm{CO}+2 \mathrm{H}_{2} \quad \Delta \mathrm{H}_{298 \mathrm{~K}}=260.5 \mathrm{~kJ} / \mathrm{mol}
$$

The hydrogen content of syngas is seen in Table 3. It is clear that steam is the preferred gasification agent for the formation of hydrogen-rich syngas. The greatest hydrogen levels of $82.9 \%$ are observed under conventional heating when the gasification reactor is paired with a syngas purification reactor. Hydrogen levels are greatest at 57\% during co-gasification. Microwave heating produces the greatest hydrogen levels under single-feeding and co-feeding, at $60 \%$ and $32.75 \%$, respectively. While the systems and heating methods are rather fascinating, it is clear that there is still a lot of unexplored territory in terms of producing hydrogen-rich syngas, particularly via co-gasification with microwave heating.

A high hydrogen yield does not always imply a high hydrogen concentration. As demonstrated in Table 4, high hydrogen yields of $>50 \mathrm{~g}$ $\mathrm{H}_{2} / \mathrm{kg}$ feedstock may be produced by co-gasification of sludge and biomass, supercritical biomass gasification, microwave-pyrolysis of gumwood, and steam gasification of lignite. This indicates that microwave technology and steam agents have a substantial influence on the creation of high hydrogen yields. Organic non-coal materials produce a large amount of hydrogen, $120 \mathrm{~g} / \mathrm{kg}$ (Parvez et al., 2019), compared to $130.87 \mathrm{~g} / \mathrm{kg}$ from coal (Zhao et al., 2021a).

\subsection{Effect of feedstock and blending ratio on hydrogen-rich syngas}

One concern of the public is MSW. Implementing gasification power

Table 3.

Hydrogen content in syngas from gasification using conventional and microwave heating.

\begin{tabular}{|c|c|c|c|c|c|}
\hline \multirow{2}{*}{ Conditions } & \multicolumn{2}{|c|}{ Conventional } & \multicolumn{2}{|c|}{ Microwave } & \multirow{2}{*}{ Ref. } \\
\hline & Single feeding & Co-feeding & Single feeding & Co-feeding & \\
\hline - Feedstock: coal. Agent: oxygen/steam & $17.72 \%$ & - & - & - & Smoliński and Howaniec (2016) \\
\hline - Feedstock: plastic waste. Gasifier: two-stage. Agent: steam & $27.3 \%$ & - & - & - & Cho et al. (2014) \\
\hline - Feedstock: Chlorella vulgaris microalgae. Agent: steam & $53.25 \%$ & - & - & - & Raheem et al. (2020) \\
\hline - Feedstock: Spirulina microalgae. Agent: steam & $41.82 \%$ & - & - & - & Raheem et al. (2020) \\
\hline $\begin{array}{l}\text { - Feedstock: MSW. Agent: air. Temperature: } 757.7^{\circ} \mathrm{C} . \text { ER: 0.24. Residence time: } \\
22.26 \mathrm{~min}\end{array}$ & $41.36 \%$ & - & - & - & Chen et al. (2020) \\
\hline - Feedstock: dry sewage sludge. Agent: oxygen/ steam. Gasifier: two-stage & $52.2 \%$ & - & - & - & Choi et al. (2015) \\
\hline - Feedstock: petroleum coke. Gasifier: pressurized fixed bed. Agent: steam & $64.2 \%$ & - & - & - & Wang et al. (2020) \\
\hline $\begin{array}{l}\text { - Feedstock: sewage sludge. Agent: steam. Gasifier: fixed bed mixed by } \mathrm{CaO} \\
\text { adsorbent. Temperature: } 650{ }^{\circ} \mathrm{C}\end{array}$ & $72.8-82.9 \%$ & - & - & - & Chen et al. (2017) \\
\hline - Feedstock: cellulose. Agent: air. Microwave: $2.45-\mathrm{GHz}, 6 \mathrm{~kW}$ & - & - & $24 \%$ & - & Sturm et al. (2016) \\
\hline - Feedstock: semi coke. Agent: steam. Microwave: $500 \mathrm{~W}$ & - & - & - & $32.75 \%$ & Zhao et al. (2021b) \\
\hline - Feedstock: dry Spirulina algae. Agent: air. Microwave: $1 \mathrm{~kW}$ & - & - & $37.58 \%$ & - & Chang et al. (2020) \\
\hline - Feedstock: Spirulina algae. Microwave: $800-1000 \mathrm{~W}$ & - & - & $36.7-45.1 \%$ & - & Lin et al. (2014a) \\
\hline - Feedstock: coal, charcoal. Agent: steam. Microwave: $6 \mathrm{~kW}, 2.45 \mathrm{GHz}$ & - & - & $45 \%$ & - & Yoon and Lee (2012) \\
\hline - Feedstock: wood pellet. Agent: steam. Microwave generator: $6 \mathrm{~kW}, 2.45 \mathrm{GHz}$ & - & - & $45-65 \%$ & - & Vecten et al. (2021) \\
\hline $\begin{array}{l}\text { - Feedstock: MSW. Microwave: } 2 \mathrm{~kW}, 2.45 \mathrm{GHz} \text {. Gasifier: integrated drying, } \\
\text { pyrolysis, and gasification }\end{array}$ & - & - & $35-53.1 \%$ & - & Beneroso et al. (2014) \\
\hline $\begin{array}{l}\text { - Feedstock: bamboo. Gasifier: microwave pyrolysis coupled with reforming using } \\
\text { activated carbon }\end{array}$ & - & - & $55.7 \%$ & - & Shi et al. (2017) \\
\hline - Feedstock: rice straw. Microwave: $1000 \mathrm{~W}$ & - & - & $56 \%$ & - & Lin et al. (2014b) \\
\hline - Feedstock: glycerol. Agent: oxygen and steam & - & - & $57 \%$ & - & Yoon et al. (2013b) \\
\hline - Feedstock: rice straw char. Agent: steam. Microwave: $550{ }^{\circ} \mathrm{C}$ & - & - & $60 \%$ & - & Xiao et al. (2015) \\
\hline - Feedstock: coal and biomass. Agent: air. Temperature: $1000{ }^{\circ} \mathrm{C}$ & - & $4.02 \%$ & - & - & Thiagarajan et al. (2020) \\
\hline - Feedstock: coal and sewage sludge. Agent: air. Gasifier: fluidized bed & - & $6.0-8.4 \%$ & - & - & Garcia et al. (2013) \\
\hline - Feedstock: $80 \%$ coal $/ 20 \%$ sewage sludge. Agent: oxygen/steam & - & $15.92 \%$ & - & - & Smoliński and Howaniec (2016) \\
\hline - Feedstock: $60 \% \mathrm{coal} / 40 \%$ sewage sludge. Agent: oxygen/steam & - & $16.31 \%$ & - & - & Smoliński and Howaniec (2016) \\
\hline $\begin{array}{l}\text { - Feedstock: woody biomass and chicken manure. Gasifier: } 10 \mathrm{~kW} \text { fixed bed } \\
\text { downdraft. Temperature: } 800-900{ }^{\circ} \mathrm{C} \text {. Agent: air }\end{array}$ & - & $18 \%$ & - & - & Ng et al. (2017) \\
\hline $\begin{array}{l}\text { - Feedstock: coal and biomass. Agent: oxygen and steam. Gasifier: bubbling } \\
\text { fluidized bed. Heater: } 30 \mathrm{~kW} \text {. Temperature: } 850{ }^{\circ} \mathrm{C} \text {. ER: } 0.2\end{array}$ & - & $35-41 \%$ & - & - & Pinto et al. (2014) \\
\hline - Feedstock: RS-PE-PVC. Agent: steam & - & $38.6-49.1 \%$ & - & - & Baloch et al. (2016) \\
\hline - Feedstock: MSW/coal char. Gasifier: three-stage. Agent: air & - & $41.9 \%$ & - & - & Hu et al. (2017) \\
\hline $\begin{array}{l}\text { - Feedstock: pine sawdust and bituminous coal. Agent: steam. Gasifier: moving bed } \\
\text { with three decoupled reactors. Bed: calcined olivine. Temperature: } 850{ }^{\circ} \mathrm{C}\end{array}$ & - & $42.4 \%$ & - & - & Tursun et al. (2016) \\
\hline $\begin{array}{l}\text { Feedstock: } 50 \% \text { biomass } / 50 \% \text { high-density polyethylene (HDPE). Agent: steam. } \\
\text { Catalyst: olive }\end{array}$ & - & $57 \%$ & - & - & Lopez et al. (2015) \\
\hline
\end{tabular}

Please cite this article as: Rosyadi I., Suyitno S., Ilyas A.X., Faishal A., Budiono A., Yusuf M. Producing hydrogen-rich syngas via microwave heating and co-gasification: a systematic review. Biofuel Research Journal 33 (2022) 1573-1591. DOI: 10.18331/BRJ2022.9.1.4 
Table 4.

Hydrogen yield from gasification using conventional heating and microwave heating.

\begin{tabular}{|c|c|c|}
\hline Technologies & Hydrogen yield (g/kg) & Ref. \\
\hline $\begin{array}{l}\text { - Hydrothermal gasification. Feedstock: soybean straw and flax straw. } \\
\text { Temperature: } 500{ }^{\circ} \mathrm{C}\end{array}$ & 13.33 & Okolie et al. (2020b) \\
\hline - Steam gasification. Fixed bed co-gasification. Feedstock: wet sewage sludge and forestry waste. Temperature: $900{ }^{\circ} \mathrm{C}$ & 23.5 & Peng et al. (2012) \\
\hline - Fluidized bed air-steam gasification. Feedstock: sewage sludge & $20-52$ & Gil-Lalaguna et al. (2014) \\
\hline - Steam gasification. Feedstock: Spirulina microalgae & 29.21 & Raheem et al. (2020) \\
\hline $\begin{array}{l}\text { - Feedstock: MSW. Agent: air. ER: 0.241. Residence time: } 22.26 \mathrm{~min} \text {. } \\
\text { Temperature: } 757^{\circ} \mathrm{C}\end{array}$ & 32.15 & Chen et al. (2020) \\
\hline - Steam gasification. Feedstock: Chlorella vulgaris & 36.04 & Raheem et al. (2020) \\
\hline - Rice straw pyrolysis, the upstream method at $1000 \mathrm{~W}$ microwave & 40.47 & Lin et al. (2014b) \\
\hline - Steam catalytic $\left(\mathrm{Ni}, \mathrm{Y}_{2} \mathrm{O}_{3}\right)$ gasification of Spirulina microalgae & 44.71 & Raheem et al. (2020) \\
\hline - Co-gasification. Feedstock: wet sewage sludge and torrefied biomass. Agent: steam. Temperature: $1100 \mathrm{~K}$ & 64. 86-67. 74 & Huang et al. (2018) \\
\hline - Supercritical gasification, air gasification, biomass feedstock & $4.1-110.5$ & $\begin{array}{l}\text { Azadi et al. (2012) } \\
\text { Elif and Nezihe (2016) }\end{array}$ \\
\hline - Microwave-pyrolysis from gumwood & 120 & Parvez et al. (2019) \\
\hline - Feedstock: lignite. Technology: looping gasification using inherent $\mathrm{CO}_{2}$ capture. Agent: steam. Catalyst: $\mathrm{NiFe}_{2} \mathrm{O}_{4}$ and $\mathrm{CuFe}_{2} \mathrm{O}_{4}$ & 130.87 & Zhao et al. (2021a) \\
\hline
\end{tabular}

plants employing MSW is hampered by low-quality syngas, low heating values, high tar contents, and acid contents (Hu et al., 2017). Apart from its low quality, the chemical and physical properties of MSW are highly dependent on its composition. Different locations generate MSW with different compositions. Aspects of raw materials, particularly changes in their composition in terms of both quality and quantity, provide several challenges to researchers, one of which is handled through the notion of co-feeding. Materials of low quality, such as MSW and biomass, as well as low-grade sludge, can be combined with high-grade fuels such as coal or polyethylene. Co-gasification of MSW or biomass with high-grade coal is an exciting possibility for zero-emissions fossil-fuel power plants while also contributing to energy security (Cormos, 2013).The next commonly explored feedstock is sludge, which is incorporated in low-grade fuels. Sludge and coal co-gasification has been studied (Lopes et al., 2006; Zhang et al., 2012; Garcia et al., 2013). The consensus is that adding wet sludge to coal boosts its catalytic reactivity. This is most likely due to the high mineral content of wet sludge. However, adding wet sludge to coal increases the release of contaminants such as $\mathrm{H}_{2} \mathrm{~S}, \mathrm{NH}_{3}$, and $\mathrm{HCl}$ (Akkache et al., 2016). Additionally, the co-gasification of sewage and textile sludge has been studied and demonstrates synergistic benefits (Nguyen and Chiang, 2021).

Abundant biomass is the potential feedstock for renewable solids. Cofeeding low-grade biomass with plastic has been proposed to avoid operational issues associated with plastic gasification, i.e., plastic feeding and minimization of the quantity of fine dust produced due to the incomplete gasification of waste plastics (Pinto et al., 2002). The improved results of co-gasification processes can be attributed to an improvement in the pre-gasification plastic pyrolysis stage. Alkali metals present in biomass ash have a catalytic influence on the cogasification of biomass and plastic. Along with plastic, biomass co-gasification with pet coke positively impacts the mixture's reactivity, lowering both the emissions and reaction times of $\mathrm{NO}_{\mathrm{x}}, \mathrm{CO}_{2}$ and $\mathrm{SO}_{\mathrm{x}}$ (Emami-Taba et al., 2012; Edreis et al., 2014; Xu et al., 2014). Additionally, biomass has been co-gasified with coal and petroleum derivatives (Aznar et al., 2006; Pinto et al., 2009; Mastellone et al., 2010). Furthermore, synergistic benefits were found when biomass pine sawdust was co-gasified with recycled tires (Yang et al., 2019). Microalgae are a form of biomass that draws much research interest as they do not compete with foodstuffs. They have also been researched in relation to cogasification with bituminous coal (Fermoso et al., 2018). Biomass can first be treated into char or activated carbon and then co-gasified with coal to improve the microwave heating performance (Wang et al., 2022). The development of co-gasification has demonstrated the synergistic impact of using two raw materials and demonstrates, in several ways, that cogasification may overcome some of the challenges associated with individual gasification and increase the quality of syngas. There is a very limited number of studies in the existing literature on microwave co-gasification such as the work on palm kernel shells and coal by
Ahmad et al. (2019), indicating that microwave co-gasification is still a relatively new field of study.

The major components of lignocellulosic biomass and coal are cellulose, hemicellulose, and lignin. Dry biomass generally comprises $40-50 \%$ cellulose, 25-35\% hemicellulose, and 10-30\% lignin. Carbohydrates hydrolyze under hydrothermal conditions to produce monomers, which are then further degraded at higher temperatures. It has been established that cellulose begins to degrade at $180{ }^{\circ} \mathrm{C}$ (Yang et al., 2020) and that its decomposition rate increases with temperature. The temperature of $180{ }^{\circ} \mathrm{C}$ has also been discovered as a critical turning point in the breakdown of cellulose when using microwave heating (Budarin et al., 2010). The reaction path for the thermal degradation of cellulose in SCWG, hydrothermal gasification, and microwave-assisted gasification is shown in Figures 11a, b, and c, respectively. Meanwhile, hemicellulose is a biopolymer that surrounds a cellulose skeleton but is different from cellulose in content and structure. Hemicellulose decomposes more quickly in water due to the presence of side chains and less homogenous structure, and hemicellulose degradation occurs between $180^{\circ} \mathrm{C}$ and $340{ }^{\circ} \mathrm{C}$ (Yang et al., 2020). Unlike cellulose and hemicellulose, lignin has an aromatic heteropolymer matrix that adds to the strength and rigidity of cell walls.

The first stage in developing a co-gasification plan for hydrogen-rich syngas is to identify source materials readily available locally in significant quantities. The following stage is to choose raw materials with a considerable amount of volatile or fixed carbon, as shown in Table 5. This stage is critical because selecting the appropriate feedstocks for co-feeding is a multi-pronged strategy toward building large plants while lowering unit operating costs, increasing efficiency, and improving emissions control (Lopez et al., 2015). However, feedstocks selected only based on their volatile or fixed carbon content may still cause problems during cogasification since high operating temperatures, such as $800-900{ }^{\circ} \mathrm{C}$, can result in the occurrence of ash slagging and fouling (Akkache et al., 2016). To address slagging and fouling, further research on slagging and fouling indices is required. For example, for olive pomace and wood scraps, the computed indexes of slagging and fouling are high. Wet sludge has moderate fouling and slagging values. On the other hand, Plastic has a low slagging and fouling index.

A critical stage in co-gasification under microwave heating is the selection of feedstocks with high dielectric characteristics. This is because microwave energy does not travel mostly by convection or conduction, as is the case with conventional heating, but rather through dielectric loss Thus, relying solely on proximate and ultimate analyses to determine the characteristics of feedstocks might result in failures in co-gasification systems aimed at yielding hydrogen-rich syngas. As a result, multiple researchers have undertaken experiments to assess the dielectric 
a

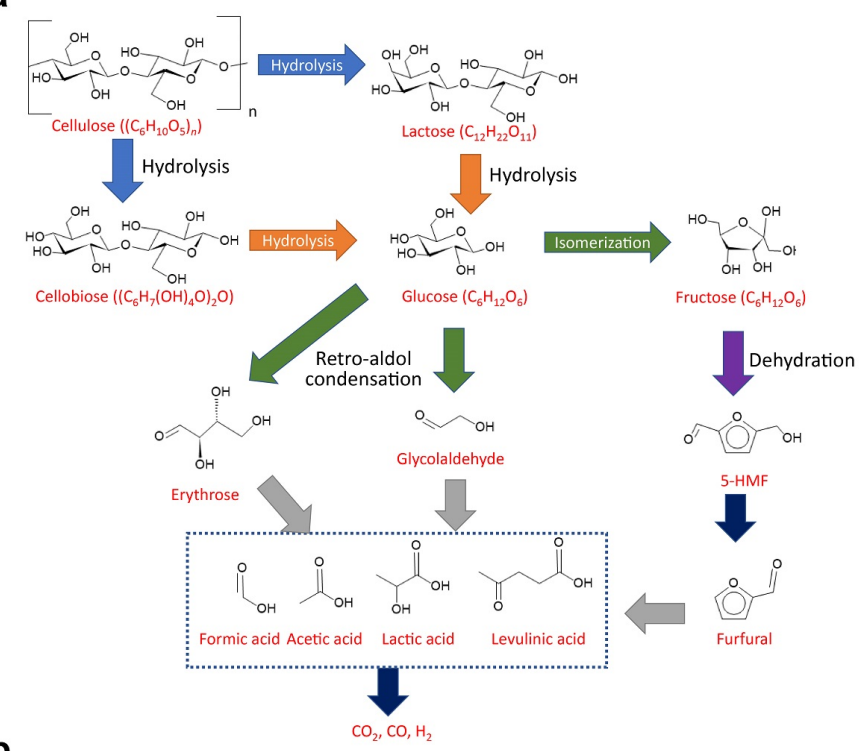

b

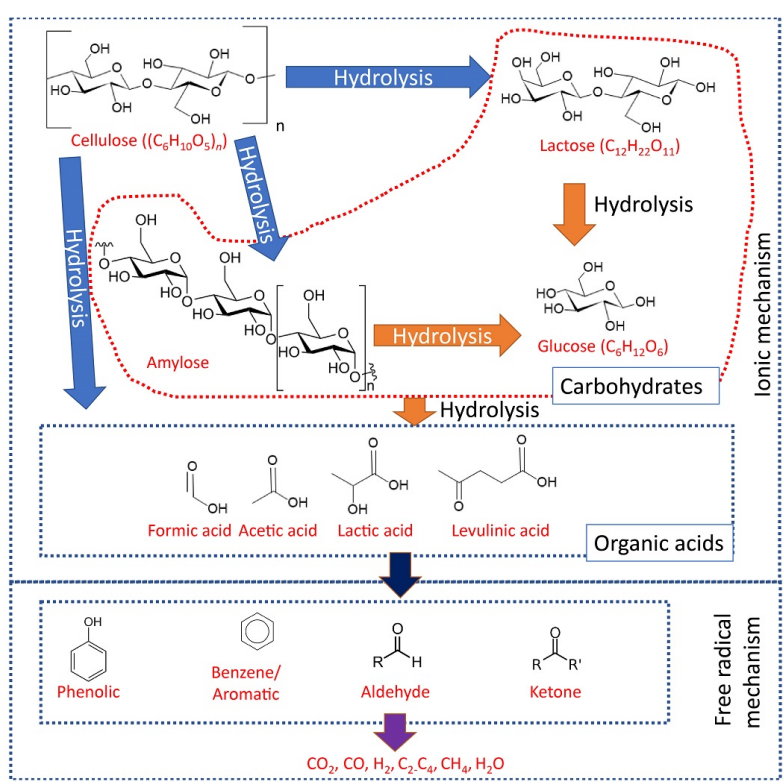

C

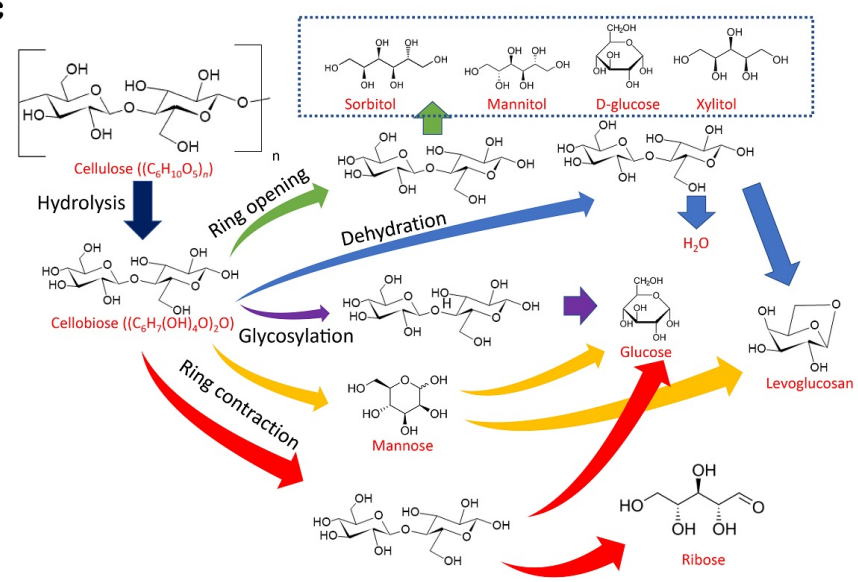

Fig. 10. Reaction pathways of cellulose in (a) subcritical water gasification (adapted from Yang et al. (2020)), (b) hydrothermal gasification (adapted from Okolie et al. (2020c)), and (c) microwave heating gasification (adapted from Budarin et al. (2010)). characteristics of various feedstocks, as well as the parameters of beds and catalysts, as illustrated in Table 6 .

According to Table 6, the poor dielectric characteristics of empty fruit bunches with an $18 \%$ moisture content, oil palm fibre, char from oil palm fibre, and coal necessitate the inclusion of microwave absorbers to assist in heating (Omar et al., 2011; Salema et al., 2013; Zhang et al., 2020 b). Coals, in general, have low microwave absorber contents because they lack graphene lattices that allow delocalized $\pi$-electrons to travel and pair with the microwave electromagnetic field. Thus, only carbonized coals, chars and cokes display strong microwave absorbance qualities due to the presence of a significant number of delocalized electrons moving on the graphene structures (Beneroso and Fidalgo, 2016). The conversion of biomass to activated carbon is a more environmentally friendly method of producing hydrogen, which also produces a valuable co-product (Demirbas, 2016). Interestingly, coconut activated carbon contains elements that provide a high $\tan \delta$ (Omar et al., 2011); as such, they are worth further development as feedstocks, adsorbents, or catalysts.

Apart from feedstocks, the conversion of microwave energy to heat can be accomplished by selecting appropriate beds, adsorbents, or catalysts The inclusion of a high concentration of silica and a moderate concentration of calcium oxide may contribute to a low loss value since these materials are known to be inert under microwave heating (Haque, 1999). Another study showed that $\mathrm{FeSO}_{4}$ has the greatest capacity for storing microwave energy and exhibiting dielectric loss, attenuation speed and microwave intensity, followed by $\mathrm{CaCl}_{2}$ and $\mathrm{K}_{2} \mathrm{CO}_{3}$. As a result, $\mathrm{FeSO}_{4}$ and $\mathrm{CaCl}_{2}$ can serve as both catalysts and microwave absorbers (Zhang et al., $2020 \mathrm{~b}$ ).

It is reasonable to predict that microwave heating results in high radiation penetration into a substance but a low conversion to energy. The polarization factor related to free and bound water relaxation may be the major determinant of the intermediate dielectric constant value. A low dielectric loss value might result from extremely little conduction and the Maxwell-Wagner effect (Metaxas and Meredith, 1983). Due to the fact that a molecular arrangement is dependent on the physical state of a material, whether solid, liquid or gas, dielectric characteristics may also vary. As a result, the dielectric polarization of compounds is dependent on their dipole moment. Due to fast molecular rotation, high dielectric constants are seen in gases and liquids. In contrast, because molecular rotation in solids is constrained, an electric field has a smaller effect on their dielectric characteristics. It is critical to note that the dielectric properties of materials, particularly the $\tan \delta$ value, are affected by the amount of water present, the temperature, and the microwave frequency used, implying that microwave gasification and co-gasification remain viable for hydrogen-rich syngas research.

\subsection{Effects of gasification agents and equivalence ratio on hydrogen-rich syngas}

Numerous gasification agents have been reported for the production of hydrogen-rich syngas, including air, oxygen (Xu et al., 2021), steam (Tursun et al., 2016; Chen et al., 2017; Cheng et al., 2019; Zhao et al., 2021b), $\mathrm{CO}_{2}$ (Ahmad et al., 2021), or mixes thereof (Gil-Lalaguna et al., 2014; Gao et al., 2017; Yousef et al., 2021). The equivalence ratio (ER) is the ratio between the actual gasification agent-fuel mixture and the stoichiometric air-fuel mixture required for complete combustion. Of pyrolysis and air vapor gasification, the latter produces significantly more hydrogen from biomass, since the combination of water and char results in the decomposition of medium biomass products, resulting in the production of hydrogen-rich gases during the subsequent water gas shift reaction (WGSR), as shown in Eq. 4.

$\mathrm{CO}+\mathrm{H}_{2} \mathrm{O} \leftrightarrow \mathrm{CO}_{2}+\mathrm{H}_{2} \quad \Delta \mathrm{H}_{298 \mathrm{~K}}=-41.5 \mathrm{~kJ} / \mathrm{mol}$

Compared to air or steam gasification, SCWG can process wet biomass directly without drying and achieves high efficiency at relatively low temperatures. SCWG gasifies biomass at a succession of temperatures and pressures over a range of residence durations, producing a mixture of $\mathrm{H}_{2}$, $\mathrm{CO}_{2}, \mathrm{CO}$, and $\mathrm{CH}_{4}$. However, the cost of hydrogen synthesis from wet biomass via SCWG is many times that of hydrogen produced by steam methane reforming (SMR) (Demirbaş, 2005). 
Table 5.

Proximate and ultimate analyses and energy content of possible feedstocks.

\begin{tabular}{|c|c|c|c|c|c|c|c|c|c|c|c|}
\hline \multirow{3}{*}{ Sample } & \multicolumn{4}{|c|}{ Proximate analysis $(\%)$} & \multicolumn{5}{|c|}{ Ultimate analysis (\%) } & \multirow{3}{*}{$\begin{array}{l}\text { Heating value } \\
(\mathrm{MJ} / \mathrm{kg})\end{array}$} & \multirow{3}{*}{ Ref. } \\
\hline & $\begin{array}{c}\text { Moisture } \\
\text { content }\end{array}$ & $\begin{array}{l}\begin{array}{l}\text { Volatile } \\
\text { matter }\end{array} \\
\end{array}$ & $\begin{array}{c}\text { Fixed } \\
\text { carbon }\end{array}$ & Ash & $\mathbf{C}$ & $\mathbf{H}$ & $\mathbf{N}$ & $\mathbf{S}$ & $\mathbf{O}$ & & \\
\hline & \multicolumn{9}{|c|}{ Biomass } & & \\
\hline Sawdust pine & 1.12 & 78.02 & 18.86 & 2.00 & 44.97 & 6.21 & 0.20 & 0.09 & 46.53 & 10.23 & Xu et al. (2021) \\
\hline Wood pellets & 7.9 & 77.8 & 14 & 0.3 & 50.9 & 6 & - & - & 42.6 & 18.9 & Bandara et al. (2021) \\
\hline Wood pellet & 6.8 & 79.6 & 13.3 & 0.3 & 50.52 & 6.12 & 0.08 & 0.3 & 42.68 & 17.47 & Vecten et al. (2021) \\
\hline Herb residue & 6.70 & 71.88 & 7.83 & 13.58 & 41.98 & 5.31 & 1.72 & 0.12 & 50.87 & 13.53 & Yan et al. (2021) \\
\hline Straw & 6.84 & 66.16 & 16.50 & 10.52 & 47.58 & 5.79 & 0.85 & 0.38 & 45.4 & 18.45 & Hu et al. (2018a) \\
\hline Oil palm shell & 7 & 69.9 & 21 & 1.8 & 49.65 & 6.43 & 8.25 & - & 35.67 & 18.3 & Ahmad et al. (2021) \\
\hline Grass pellets & 8.4 & 69.5 & 12.6 & 9.49 & 46.9 & 5.7 & 3.19 & - & 33.7 & 16.7 & Bandara et al. (2021) \\
\hline Rice husk & 9.68 & 73.32 & 4.8 & 12.2 & 38.26 & 5.26 & 1.72 & 0.05 & 32.83 & - & Luo et al. (2022) \\
\hline Refused derived fuel & 9.16 & 58.57 & 9.35 & 22.92 & 41.2 & 5.81 & 0.42 & 0.23 & 40.27 & 16.03 & Cai et al. (2021) \\
\hline Microalgae & 3.9 & 82.91 & 7.12 & 6.07 & 50.67 & 7.35 & 6.54 & - & 35.44 & - & Liu et al. (2021) \\
\hline Soybean stalk & 1.60 & 79.97 & 20.35 & 7.08 & 52.33 & 6.41 & 0.49 & 0.05 & 38.08 & - & Yao et al. (2019) \\
\hline \multicolumn{12}{|c|}{ Char } \\
\hline Charcoal & 0.60 & 27.61 & 70.37 & 1.42 & 83.33 & 3.63 & 0.43 & 0.004 & 11.19 & 30.3 & Yoon and Lee (2012) \\
\hline \multicolumn{12}{|c|}{ Sludge } \\
\hline Sewage sludge & 6.48 & 50.09 & 4.39 & 39.04 & 29.5 & 4.67 & 5.27 & 1.31 & 59.25 & 11.8 & Gil-Lalaguna et al. (2014) \\
\hline Wet sewage sludge & 80.07 & 9.78 & 1.84 & 8.31 & 6.27 & 1.09 & 0.77 & 0.28 & 3.2 & 0.58 & Chiang et al. (2016) \\
\hline Paper-mill sludge & 51.37 & 29.88 & 0.42 & 18.33 & 13.89 & 2.03 & 0.42 & 0.15 & 13.77 & 2.26 & Chiang et al. (2016) \\
\hline \multicolumn{12}{|c|}{ Municipal solid waste (MSW) } \\
\hline MSW & 51.87 & 57 & 12.19 & 30.81 & 40.44 & 4.75 & 0.94 & 1.72 & 21.13 & 15 & Tungalag et al. (2020) \\
\hline \multicolumn{12}{|c|}{ Plastic } \\
\hline Plastics & 0.38 & 94.71 & 4.37 & 0.54 & 82.41 & 13.42 & 0.18 & - & 2.86 & 43.7 & Cho et al. (2014) \\
\hline \multicolumn{12}{|c|}{ Coal } \\
\hline Shenhua coal & 5.17 & 31.71 & 57.32 & 5.80 & 67.46 & 4.96 & 1.03 & 0.71 & 14.84 & 27.1 & Yoon and Lee (2012) \\
\hline
\end{tabular}

Table 6.

The dielectric properties for feedstocks, bed, and catalysts.

\begin{tabular}{|c|c|c|c|c|}
\hline Materials & Dielectric constant & Loss factor & Tangent loss & Ref. \\
\hline Oil palm fiber & 1.99 & 0.16 & 0.08 & Salema et al. (2013) \\
\hline Coal & 2.6649 & 0.026 & 0.01 & Zhang et al. (2020b) \\
\hline Char of oil palm fiber & 2.83 & 0.23 & 0.08 & Salema et al. (2013) \\
\hline $\mathrm{K}_{2} \mathrm{CO}_{3}$ & 4.9571 & 0.1527 & 0.031 & Zhang et al. (2020b) \\
\hline \multicolumn{5}{|c|}{ Moderate dielectric properties } \\
\hline Oil palm shell & 2.79 & 0.35 & 0.12 & Salema et al. (2013) \\
\hline Char of empty fruit bunch & 3.5 & 0.47 & 0.13 & Omar et al. (2011) \\
\hline $\mathrm{CaCl}_{2}$ & 11.7936 & 3.3752 & 0.286 & Zhang et al. (2020b) \\
\hline $\mathrm{FeSO}_{4}$ & 14.2305 & 4.4429 & 0.3122 & Zhang et al. (2020b) \\
\hline $\mathrm{SiC}$ & 30.000 & 11.000 & 0.367 & Stefanidis et al. (2014) \\
\hline Palm kernel shell activated carbon & 55.7 & 22.1 & 0.40 & Omar et al. (2011) \\
\hline Oil palm trunk core & 18 & 5 & 0.28 & Jie et al. (2015) \\
\hline \multicolumn{5}{|c|}{ High dielectric properties } \\
\hline Coconut activated carbon & 22.9 & 37.7 & 1,64 & Omar et al. (2011) \\
\hline
\end{tabular}

Please cite this article as: Rosyadi I., Suyitno S., Ilyas A.X., Faishal A., Budiono A., Yusuf M. Producing hydrogen-rich syngas via microwave heating and co-gasification: a systematic review. Biofuel Research Journal 33 (2022) 1573-1591. DOI: 10.18331/BRJ2022.9.1.4 
Gasification agents that have been tested with microwave gasification technology include $\mathrm{CO}_{2}$ (Lahijani et al., 2014; Chun and Song, 2020), steam (Djebabra et al., 1991; Sekiguchi and Orimo, 2004; Yoon and Lee, 2012; Shin et al., 2013; Liu et al., 2019), and air (Yoon and Lee, 2012; Yoon et al., 2013a). Steam gasification agents continue to outperform air and $\mathrm{CO}_{2}$. This is in addition to the fact that a steam agent is capable of producing hydrogen-rich syngas.

An ER of 0.35 results in a high lower heating value (LHV) of $12.2 \mathrm{MJ} / \mathrm{m}^{3}$ during coal gasification using air agents. LHV concentrations decrease to 10.9 and $10.5 \mathrm{MJ} / \mathrm{m}^{3}$ at $\mathrm{ER}=0.25$ and 0.45 , respectively. Low ER values indicate a lack of air, which may result in a lack of $\mathrm{CO}_{2}$ and $\mathrm{H}_{2} \mathrm{O}$ reactants. On the other hand, if an overabundance of oxygen leads to an increase in $\mathrm{CO}_{2}$ in syngas, the LHV decreases. Due to the increased oxidation of hydrocarbons, particularly tar micromolecular hydrocarbons, an improved ER appears to result in an increase in gas production. Additionally, in addition to LHV, changes in ER have a major influence on cold gas efficiency (CGE) and CCE (Hu et al., 2017). The ER is typically chosen as $0.1-0.5$, with $0.2-0.3$ being the best range for producing hydrogen-rich syngas (Schmid et al., 2021). Alternatively, it is also common to use steam-to-carbon ratio (S/C) in steam gasification instead of ER. A low S/C can lower char conversion and increase tar yields. As $\mathrm{H}_{2} \mathrm{O}$ encourages the balanced creation of hydrogen and carbon dioxide, the shifting reaction of water gas is significantly impacted by the S/C. As a consequence, raising the S/C ratio by 1.5-2.5 can increase $\mathrm{H}_{2}$ outcomes as well as $\mathrm{H}_{2} / \mathrm{CO}$ ratios, which are critical for downstream synthesis processes (Schmid et al., 2021).

\subsection{Effects of temperature and pressure on hydrogen-rich syngas}

High temperatures are observed to improve hydrogen and carbon monoxide concentrations, carbon conversion, and CGE during gasification and cogasification processes (Emami-Taba et al., 2012). The fundamental reason for this is that the key processes in gasification (Eqs. 1 and 2) are endothermic, which means that the rate of the gasification reactions increases with temperature. As a result, temperatures $>700{ }^{\circ} \mathrm{C}$ are widely utilized. In gasification and co-gasification processes involving some types of biomass, too-high temperatures are undesirable due to the presence of ash, which may melt at high temperatures.

When biomass or coal solids are heated traditionally, the gasification process commonly results in the melting of chlorides $\left(\mathrm{CaCl}_{2}\right.$ and $\left.\mathrm{MgCl}_{2}\right)$, formed when metal oxides react with $\mathrm{HCl}$ in char. Slagging develops due to the melting of this ash, which significantly lowers the activity of heterogeneous processes and tar-cracking reactions (Hu et al., 2017). $\mathrm{CaCl}_{2}$ and $\mathrm{MgCl}_{2}$ have melting temperatures of $782{ }^{\circ} \mathrm{C}$ and $714{ }^{\circ} \mathrm{C}$ and boiling points of $1600{ }^{\circ} \mathrm{C}$ and $1412{ }^{\circ} \mathrm{C}$, respectively. As a result, the working temperatures of gasification and co-gasification are between $700^{\circ} \mathrm{C}$ and $1000^{\circ} \mathrm{C}$, which are between the melting and the boiling points of $\mathrm{CaCl}_{2}$ and $\mathrm{MgCl}_{2}$, resulting in coal char slagging and agglomeration. Owing to the existence of slagging and agglomeration, the Brunauer-Emmett-Teller (BET) specific surface area of coal char of $127.6 \mathrm{~m}^{2} / \mathrm{g}$ is reduced to $74.9 \mathrm{~m}^{2} / \mathrm{g}$ (Kai et al., 2017).

If the goal is to optimize the output of hydrogen-rich syngas produced by gasification or co-gasification, a moderate temperature, slow heating rate, and long residence time are recommended. The most significant impact is temperature, which affects most of the response variables assessed during gasification and co-gasification processes. Increased temperatures are beneficial in lowering the amount of tar in the syngas and maximizing gas production, efficiency, and carbon conversion (Gil-Lalaguna et al., 2014). Research indicates that the energy rates of heated gases are $23 \%$ greater using microwaves than with conventional heating (Parvez et al., 2019).

Pressure, on the other hand, plays a crucial role in conventionally-heated gasification (Wolfesberger et al., 2009), microwave-assisted gasification (Wnukowski et al., 2021), hydrothermal gasification, and SCWG (Sheikhdavoodi et al., 2015). In conventionally-heated gasification, high temperatures of up to $950{ }^{\circ} \mathrm{C}$ and pressures of up to 10 bar result in lower tar concentrations (Wolfesberger et al., 2009). Gasification of supercritical water at $25 \mathrm{MPa}$ and temperatures of $400-800{ }^{\circ} \mathrm{C}$ with a sugarcane bagasse raw material has been investigated in batch reactors at a constant pressure of 25 $\mathrm{MPa}$, with the largest quantity of hydrogen $\left(75.6 \mathrm{~mol} \mathrm{~kg}^{-1}\right)$ obtained at $800{ }^{\circ} \mathrm{C}$ (Sheikhdavoodi et al., 2015). In practice, temperature, pressure, feedstock type (coal, biomass or their blends), and ER all affect hydrogen-rich syngas production. Furthermore, while all of these factors are important and interconnected during gasification, temperature is most vital.

\subsection{Catalytic effect on hydrogen-rich syngas}

Microwaves are inextricably related to catalysts, just as they are with feedstock. Catalysts speed-up reactions in a unique way. The catalyst's role is to lower the activation energy sufficiently to allow the majority of particles to react. Catalysts can reduce a reaction's activation energy by guiding the interacting particles in a way that maximizes the probability of successful contact. The second technique entails interacting with reactants in order to develop intermediates that require less energy to convert to products.

$\mathrm{K}_{2} \mathrm{CO}_{3}$ is the preferred alkali catalyst for coal SCWG due to its high catalytic activity and low cost (Zhang et al., 2021). The yield of $\mathrm{H}_{2}$ improves when $\mathrm{K}_{2} \mathrm{CO}_{3}$ is used as a catalyst. However, the addition of $\mathrm{K}_{2} \mathrm{CO}_{3}$ introduces ash aggregation. The formation of a K-bearing eutectic leads to a reduction in carbon gasification efficiency and long-term shutdown of the reaction system (Mastuli et al., 2019). It has also been discovered that when $\mathrm{NaOH}$ and $\mathrm{KOH}$ are used as catalysts for SCWG of bagasse, a significant rise in $\mathrm{H}_{2}$ generation occurs (Sheikhdavoodi et al., 2015). Nonetheless, $\mathrm{K}_{2} \mathrm{CO}_{3}$ is less appropriate for gasification and cogasification by microwave heating due to its limited capacity to convert microwave energy to heat, as measured by $\tan \delta=0.031$ (Zhang et al. 2020b).

When applied to flue gas streams from solid fuel combustion, calcium refining is believed to be an effective technology for absorbing $\mathrm{CO}_{2}$ and eliminating contaminants (Dashtestani et al., 2021). $\mathrm{CaO}$ facilitates the development of low-melting-point albite and anorthite. However, more $\mathrm{Al}_{2} \mathrm{O}_{3}$ addition leads to the formation of high-melting-point mullite, which is why alkaline materials derived from $\mathrm{Al}_{2} \mathrm{O}_{3}$ are not extensively utilized as catalysts in co-gasification processes (Shi et al., 2021). The key drawback of $\mathrm{CaO}$ sorbents is that their ability to absorb $\mathrm{CO}_{2}$ is readily diminished by up to $80 \%$ after many cycles, leading to a shift in the $\mathrm{CO}_{2}$ reaction's equilibrium (Granados-Pichardo et al., 2020). This is because of the sintering and clumping of $\mathrm{CaO}$ particles, which results in a decrease in surface area (Gao et al., 2017). Meanwhile, magnesium oxide (MgO) can operate as a framework and limit the sintering and agglomeration caused by the interaction of $\mathrm{CO}_{2}$ with $\mathrm{CaO}$-based sorbents at elevated temperatures (Papalas et al., 2021). $\mathrm{CaO}$ and $\mathrm{MgO}$ are added to WGSR to alter the thermodynamic equilibrium by collecting $\mathrm{CO}_{2}$ and increasing $\mathrm{H}_{2}$ generation (Bunma and Kuchonthara, 2018).

Noble metal-based catalysts are generally claimed to be less susceptible to coking than catalysts based on transition metals (e.g., Ni, Fe, Co, Pd, etc.) (Rostrupnielsen and Hansen, 1993; Effendi et al., 2003). While some noble metals exhibit excellent selectivity, their high cost and scarcity preclude their practical usage. As a result, different catalysts have been utilized to produce hydrogen-rich syngas, such as $\mathrm{K} / \mathrm{Ca}$ (Koido et al., 2021), $\mathrm{Mg}_{0.8} \mathrm{Zn}_{0.20} \mathrm{O}$ (Mastuli et al., 2019), $\mathrm{Ni} / \mathrm{Al}_{2} \mathrm{O}_{3}$ (Xie et al., 2014), and $\mathrm{Ni}-\mathrm{CaO}$ (Irfan et al., 2021). Additionally, carbon-based catalysts or activated carbon have several benefits over metal catalysts (Muradov et al., 2006a and b) However, because the dielectric characteristics of these catalysts are unknown, there is still huge potential to investigate them further for use in microwave heating.

Along with catalysts, solid materials, such as bed and adsorbent, are employed to absorb heat during gasification. Calcination dolomite is utilized as bed material. Meanwhile, activated carbon is used as a tarcracking ingredient in syngas production with a low-tar and high-hydrogen content (Cho et al., 2013). The quantity of activated carbon adsorbent seems to have a significant effect on tar removal and $\mathrm{H}_{2}$ generation. When calcined dolomite and activated carbon are used as the fluidizing bed material, the $\mathrm{H}_{2}$ concentration is $26.1 \mathrm{vol} \%$, and the total tar content is almost $96 \%$ less than when silica sand is used (Cho et al., 2013).

\subsection{Heating value of hydrogen-rich syngas}

Meanwhile, previous research has established that extremely high temperatures reduce the concentrations of combustible gases, such as $\mathrm{CO}$, $\mathrm{CH}_{4}$, and $\mathrm{H}_{2}$, resulting in a decrease in LHV. At temperatures between 800 
and $1000{ }^{\circ} \mathrm{C}$, the energy content of syngas decreases from 12.2 to $10.6 \mathrm{MJ} / \mathrm{m}^{3}$ (Hu et al., 2017). Syngas LHV of $12.2 \mathrm{MJ} / \mathrm{m}^{3}$ is attained at ER 0.35 . Moreover, the cold gas conversion efficiency is $63.4 \%$, and the CCE is $66.0 \%$ at a gasification temperature of $1000{ }^{\circ} \mathrm{C}$ ( $\mathrm{Hu}$ et al., 2017). At elevated temperatures, the Boudouard reaction is the dominant reaction, followed by the WGSR (Hu et al., 2017). A high temperature must be addressed to avoid the slagging and blockage of chlorides in the coal char (Cho et al., 2015). High LHV values of syngas correlate with the gasification reactor's efficiency. The efficiency of cold gasification is defined as the ratio of energy contained in the gas products to that in the raw materials. Experimental values for CGE range from $39 \%$ to $66 \%$. As shown in Table 7, microwave heating enables high LHV values of up to $17.44 \mathrm{MJ} / \mathrm{m}^{3}$ (Lupa et al., 2013), indicating that this technique is worth developing to create syngas rich in hydrogen with a high hydrogen yield, high heat value, and improved CGE and CCE.

Table 7.

Heating value of syngas produced from gasification.

\begin{tabular}{|c|c|c|}
\hline Technology & LHV of syngas $\left(\mathrm{MJ} / \mathrm{m}^{3}\right)$ & Ref. \\
\hline $\begin{array}{l}\text { Co-gasification } \\
\text { - Feedstock: coal and biomass } \\
\text { - Temperature: } 1000{ }^{\circ} \mathrm{C}\end{array}$ & $1.5-2.0$ & Thiagarajan et al. (2020) \\
\hline $\begin{array}{l}\text { Co-gasification } \\
\text { - Feedstock: sewage sludge and paper-mill sludge } \\
\text { - Gasifier: fluidized bed } \\
\text { - Temperature: } 900{ }^{\circ} \mathrm{C} \\
\text { - Air to fuel ratio: } 0.3\end{array}$ & $1.67-2.56$ & Chiang et al. (2016) \\
\hline $\begin{array}{l}\text { Co-gasification } \\
\text { - Gasifier: fluidized bed } \\
\text { - Agent: air }\end{array}$ & $1.9-4.1$ & Garcia et al. (2013) \\
\hline $\begin{array}{l}\text { Co-gasification } \\
\text { - Fluidized bed, air-steam gasification, sewage sludge feedstock }\end{array}$ & $4.12-6.20$ & Gil-Lalaguna et al. (2014) \\
\hline $\begin{array}{l}\text { Co-gasification } \\
\text { - Feedstock: } 30 \mathrm{wt} \% \text { chicken manure and } 70 \mathrm{wt} \% \text { wood wastes } \\
\text { - Gasifier: fixed bed downdraft } \\
\text { - Capacity: } 10 \mathrm{~kW} \\
\text { - Temperature: } 800-900{ }^{\circ} \mathrm{C}\end{array}$ & 5.23 & $\mathrm{Ng}$ et al. (2017) \\
\hline $\begin{array}{l}\text { Gasification } \\
\text { - Gasifier: two-stage } \\
\text { - Agent: oxygen/steam }\end{array}$ & 9.3 & Choi et al. (2015) \\
\hline $\begin{array}{l}\text { Gasification } \\
\text { - Feedstock: biomass } \\
\text { - Gasifier: fluidized bed } \\
\text { - Agent: steam } \\
\text { - Catalyst: } \mathrm{Ni} / \mathrm{Al}_{2} \mathrm{O}_{3} \\
\text { - Microwave } \\
\text { - Temperature: } 900{ }^{\circ} \mathrm{C}\end{array}$ & $9.31-11.15$ & Xie et al. (2014) \\
\hline $\begin{array}{l}\text { Co-gasification } \\
\text { - Feedstock: wastewater sludge, waste wood, reeds, olive pomace, solid } \\
\text { recovered fuel, paper, and plastic } \\
\text { - Gasifier: fixed bed reactor } \\
\text { - Temperature: } 850^{\circ} \mathrm{C}\end{array}$ & $9.0-11.9$ & Akkache et al. (2016) \\
\hline $\begin{array}{l}\text { Gasification } \\
\text { - Feedstock: biomass } \\
\text { - Microwave gasification } \\
\text { - microwave power: } 6 \mathrm{~kW} \\
\text { - Agent: steam }\end{array}$ & $10.5-12$ & Vecten et al. (2021) \\
\hline $\begin{array}{l}\text { Co-gasification } \\
\text { - Feedstock: MSW/coal char } \\
\text { - Gasifier: three stage gasification } \\
\text { - Temperature: } 800{ }^{\circ} \mathrm{C}\end{array}$ & 12.2 & Hu et al. (2017) \\
\hline $\begin{array}{l}\text { Gasification } \\
\text { - Feedstock: MSW } \\
\text { - Agent: air } \\
\text { - ER: } 0.24\end{array}$ & $9.33-12.48$ & Chen et al. (2020) \\
\hline $\begin{array}{l}\text { Co-gasification } \\
\text { - Feedstock: wet sewage sludge and forestry waste } \\
\text { - Gasifier: fixed bed } \\
\text { - Agent: steam } \\
\text { - Temperature: } 700-900{ }^{\circ} \mathrm{C}\end{array}$ & $11.89-12.72$ & Peng et al. (2012) \\
\hline $\begin{array}{l}\text { Co-gasification } \\
\text { - Feedstock: PE/PVC/RS } \\
\text { - Temperature: } 900{ }^{\circ} \mathrm{C}\end{array}$ & $11.9-15.4$ & Baloch et al. (2016) \\
\hline $\begin{array}{l}\text { Co-gasification } \\
\text { - microwave-induced plasma }\end{array}$ & $11.39-17.44$ & Lupa et al. (2013) \\
\hline
\end{tabular}

Please cite this article as: Rosyadi I., Suyitno S., Ilyas A.X., Faishal A., Budiono A., Yusuf M. Producing hydrogen-rich syngas via microwave heating and co-gasification: a systematic review. Biofuel Research Journal 33 (2022) 1573-1591. DOI: 10.18331/BRJ2022.9.1.4 


\section{Economic and environmental sustainability aspects}

Depending on the designation, air gasification that produces low-heatingvalue syngas of 4-6 MJ/m $3 \mathrm{~m}^{3}$ and $8-14 \mathrm{vol} \% \mathrm{H}_{2}$ can be improved in quality by using a pure oxygen supply, which has cost and safety consequences. Biomass steam gasification can generate gas with a medium caloric value $\left(10-16 \mathrm{MJ} / \mathrm{m}^{3}\right)$ and, in particular, gas with a high hydrogen content (30-60 vol\%) (Xiao et al., 2011). Therefore, the most expensive method is oxygen gasification, followed by steam and air gasification in terms of expense (Hosseinzadeh et al., 2022). Biomass gasification, a keyword that frequently appears in cluster analysis on VOSviewer, has feedstock prices, feedstock costs, and production costs of US\$2-5/GJ, US\$2.9-7.1/GJ $\mathrm{H}_{2}$, and US\$5-6/GJ $\mathrm{H}_{2}$, respectively. Hydrogen produced through the biomass gasification and coal gasification processes is still more expensive than that produced through SMR (Parthasarathy and Narayanan, 2014).

Keywords plasma gasification and supercritical water gasification have attracted much study, which has revealed certain issues, as shown in Figure 6. The cost of creating hydrogen is several times greater than with steam gasification or SMR (Parthasarathy and Narayanan, 2014; Udomsirichakorn and Salam, 2014). Nonetheless, SCWG promises to convert wet biowaste directly into hydrogen without the need for an energy-intensive pre-drying step (Su et al., 2022). As shown in VOSviewer (Fig. 1), the keywords economic analysis and hydrogen production have different clusters. This implies that the cost of creating hydrogen gas at the capacity of the fluidized beds used in basic research is now uncertain because little data is available in the literature. However, without such economic figures, full techno-economic analyses are not yet conceivable (Fremaux et al., 2015). Meanwhile, it is expected that hydrogen-rich syngas will be cost-competitive in the long run. Fluctuation in feedstock prices and the projected usage of $\mathrm{CO}_{2}$ capture and storage (CCS) in fossil fuel-based processes must be considered. As a result, the development of co-gasification solutions with diversified feedstocks and competitive costs may become very appealing, particularly at hydrogen-production scales $>100 \mathrm{t} / \mathrm{d}$ (Udomsirichakorn and Salam, 2014).

From an environmental standpoint, the tar and $\mathrm{CO}_{2}$ produced during the gasification process are unavoidably problematic. When the hydrogen extracted from a stream of hydrogen-rich gases includes impurities such as $\mathrm{CO}_{2}, \mathrm{CH}_{4}, \mathrm{CO}$, and tar, this might cause large expenditures in commercial applications. Thus, if $\mathrm{CO}_{2}$ and tar produced during gasification can be caught and cracked simultaneously, these technologies become substantially more desirable and cost-effective for hydrogen generation (Udomsirichakorn and Salam, 2014). However, capturing the $\mathrm{CO}_{2}$ created adds roughly $25-30 \%$ to the original cost of hydrogen synthesis.

In terms of environmental sustainability, conventional gasification produces less $\mathrm{CO}_{2}$ than plasma gasification. Coal gasification generates $18.0 \mathrm{~kg} \mathrm{CO}_{2}$ $\mathrm{eq} / \mathrm{kg} \mathrm{H}_{2}$ (Chen et al., 2019), whereas plasma gasification generates $31 \mathrm{~kg} \mathrm{CO}_{2}$ eq/kg MSW (Ramos et al., 2019). Furthermore, a comparison of various research indicates that the results of the life cycle analysis of biomass-tohydrogen processes are superior to those of the life cycle analysis of coal-tohydrogen production. According to this research, the life cycle energy consumption of the biomass-based hydrogen-production process is roughly one-fourth that of the coal-based process.

Finally, attention must be paid to the existence of tar, in addition to the hydrogen concentration, hydrogen yield, LHV, CGE, and CCE. Tar is one of the difficulties that must be solved in syngas production since it can clog gasifier equipment, piping, and power plant systems. The tar content of raw gas can be decreased from around $40 \mathrm{~g} / \mathrm{m}^{3}$ to $10 \mathrm{~g} / \mathrm{m}^{3}$ by utilizing a two-stage gasification technique in conjunction with $\mathrm{Ca}$ impregnation. Tar with a concentration of $17.6 \mathrm{~g} / \mathrm{Nm}^{3}$ is capable of co-gasifying MSW and coal char in a three-stage gasification process (Hu et al., 2017). Co-gasification may also be utilized to reduce tar from 58.23 to $9.74 \mathrm{~g} / \mathrm{Nm}^{3}$ when $50 \%$ high-density polyethylene (HDPE) is used as a feedstock (Lopez et al., 2015). A reduced tar concentration of $5.8 \mathrm{~g} / \mathrm{Nm}^{3}$ was successfully generated from three decoupled reactors co-gasifying biomass/coal feedstock at $850{ }^{\circ} \mathrm{C}$ utilizing steam agents (Tursun et al., 2016). Thus, it is worthwhile to continue developing cogasification systems with microwave heating that generate syngas with a high hydrogen content, high hydrogen yield, high CGE/CCE ratio, and low tar level.

\section{Conclusions and future works}

We conducted a thorough assessment of gasification and co-gasification systems that use either conventional or microwave heating to produce hydrogen-rich syngas. The factors of hydrogen concentration, hydrogen production, CGE, CCE, and tar content were considered. The following are the key findings:

- Microwaves may convert energy into heat within solids, thereby improving heat dispersion and increasing the quantity of syngas. However, the processes and mechanisms that can boost the hydrogen concentration of syngas must be investigated further.

- Coconut activated carbon comprises components that give high tan $\delta$ values and so merit further investigation as raw materials, adsorbents or catalysts. Materials with a $\tan \delta>0.5$ are required for microwave-assisted gasification.

- Co-gasification is critical for the production of hydrogen-rich syngas because it tackles the issue of raw material unpredictability while delivering synergistic benefits. The blending ratios suitable for microwave-assisted co-gasification must be thoroughly investigated in order to create syngas with high hydrogen content.

- While microwave heating is superior to conventional heating, the quantity of hydrogen produced remains small, at $60 \%$ and $32.75 \%$ for single-feeding and co-feeding processes, respectively. Furthermore, syngas generated via microwave heating has a heating value of $17.44 \mathrm{MJ} / \mathrm{m}^{3}$, which is significantly higher than that of conventional heating.

- Steam gasification agents can generate hydrogen-rich syngas. Steam gasification, hydrothermal gasification, and SCWG are necessary to create hydrogen at a rate of $57 \%$, which can be enhanced to $82.9 \%$ by employing purification technology. Such an increase is critical so that hydrogen can be utilized immediately in the industrial sector.

- Gasification, in conjunction with microwave heating, necessitates the careful selection of source materials with high dielectric constants. The dielectric characteristics of raw materials, beds, adsorbents, and catalysts should be investigated further to improve the performance of microwave-heated, hydrogen-rich syngasgeneration technology.

- Hydrogen-rich syngas generation strategies based on shared gasification and microwave heating are currently underutilized and have the potential to be expanded at both the laboratory and commercial scales.

\section{Acknowledgements}

The authors wish to express their gratitude to the Rector of Sebelas Maret University for the funding provided by RKAT PTNBH Sebelas Maret University for Fiscal Year 2022 via the DIPA's Deputy for Research and Development Strengthening, Ministry of Research and Technology/BRIN via Applied Research Excellence in Higher Education (PTUPT) No. 0054/E5/AK.04/2022.

\section{References}

[1] Ahmad, N.A., Al-attab, K.A., Zainal, Z.A., Lahijani, P., 2021 Microwave assisted steam- $\mathrm{CO}_{2}$ char gasification of oil palm shell Bioresour. Technol. Reports. 15, 100785.

[2] Ahmad, R., Ishak, M.A.M.M., Ismail, K., Kassim, N.N., Kasim, N.N. 2019. Influence of microwave pre-treated Palm Kernel Shell and Mukah Balingian coal on co-gasification. J. Mech. Eng. Sci. 13(4), 5791-5803.

[3] Ahmad, S.S., Morgan, M.T., Okos, M.R., 2001. Effects of microwave on the drying, checking and mechanical strength of baked biscuits. J. Food Eng. 50(2), 63-75. 
[4] Akkache, S., Hernández, A.B., Teixeira, G., Gelix, F., Roche, N., Ferrasse, J.H., 2016. Co-gasification of wastewater sludge and different feedstock: feasibility study. Biomass Bioenergy. 89, 201-209.

[5] Al-Rahbi, A.S., Williams, P.T., 2017. Hydrogen-rich syngas production and tar removal from biomass gasification using sacrificial tyre pyrolysis char. Appl. Energy. 190, 501-509.

[6] Arpia, A.A., Nguyen, T.B., Chen, W.H., Dong, C.D., Ok, Y.S., 2022. Microwave-assisted gasification of biomass for sustainable and energyefficient biohydrogen and biosyngas production: a state-of-the-art review. Chemosphere. 287, 132014.

[7] Azadi, P., Khan, S., Strobel, F., Azadi, F., Farnood, R., 2012. Hydrogen production from cellulose, lignin, bark and model carbohydrates in supercritical water using nickel and ruthenium catalysts. Appl. Catal., B. 117, 330-338.

[8] Aznar, M.P., Caballero, M.A., Sancho, J.A., Francés, E., 2006. Plastic waste elimination by co-gasification with coal and biomass in fluidized bed with air in pilot plant. Fuel Process. Technol. 87(5), 409-420.

[9] Bai, X., Tiwari, S., Robinson, B., Killmer, C., Li, L., Hu, J., 2018. Microwave catalytic synthesis of ammonia from methane and nitrogen. Catal. Sci. Technol. 8(24), 6302-6305.

[10] Baloch, H.A., Yang, T., Li, R., Nizamuddin, S., Kai, X., Bhutto, A.W., 2016. Parametric study of co-gasification of ternary blends of rice straw, polyethylene and polyvinylchloride. Clean Technol. Environ. Policy. 18(4), 1031-1042.

[11] Bandara, J.C., Jaiswal, R., Nielsen, H.K., Moldestad, B.M.E., Eikeland, M.S., 2021. Air gasification of wood chips, wood pellets and grass pellets in a bubbling fluidized bed reactor. Energy. 233, 121149.

[12] Beheshti, S.M., Ghassemi, H., Shahsavan-Markadeh, R., 2015. Process simulation of biomass gasification in a bubbling fluidized bed reactor. Energy Convers. Manage. 94, 345-352.

[13] Beneroso, D., Bermúdez, J.M., Arenillas, A., Menéndez, J.A., 2014. Integrated microwave drying, pyrolysis and gasification for valorisation of organic wastes to syngas. Fuel. 132, 20-26.

[14] Beneroso, D., Fidalgo, B., 2016. Microwave technology for syngas production from renewable sources, in: Myers, R. (Ed.), Syngas. Nova Science Publishers Inc., pp. 117 - 152.

[15] Budarin, V.L., Clark, J.H., Lanigan, B.A., Shuttleworth, P., Macquarrie, D.J., 2010. Microwave assisted decomposition of cellulose: a new thermochemical route for biomass exploitation. Bioresour. Technol. 101(10), 3776-3779.

[16] Bunma, T., Kuchonthara, P., 2018. Synergistic study between $\mathrm{CaO}$ and $\mathrm{MgO}$ sorbents for hydrogen rich gas production from the pyrolysisgasification of sugarcane leaves. Process Saf. Environ. Prot. 118, 188194

[17] Cai, J., Zeng, R., Zheng, W., Wang, S., Han, J., Li, K., Luo, M., Tang, X., 2021. Synergistic effects of co-gasification of municipal solid waste and biomass in fixed-bed gasifier. Process Saf. Environ. Prot. 148, 1-12.

[18] Chan, Y.H., Rahman, S.N.F.S.A., Lahuri, H.M., Khalid, A., 2021. Recent progress on $\mathrm{CO}$-rich syngas production via $\mathrm{CO}_{2}$ gasification of various wastes: a critical review on efficiency, challenges and outlook. Environ. Pollut. 278, 116843 .

[19] Chang, K.L., Lin, Y.C., Shangdiar, S., Chen, S.C., Hsiao, Y.H., 2020. Hydrogen production from dry spirulina algae with downstream feeding in microwave plasma reactor assisted under atmospheric pressure. J. Energy Inst. 93(4), 1597-1601

[20] Chen, G., Jamro, I.A., Samo, S.R., Wenga, T., Baloch, H.A., Yan, B., Ma, W., 2020. Hydrogen-rich syngas production from municipal solid waste gasification through the application of central composite design: an optimization study. Int. J. Hydrogen Energy. 45(58), 33260-33273.

[21] Chen, J., Xu, W., Wu, X., Jiaqiang, E., Lu, N., Wang, T., Zuo, H., 2019. System development and environmental performance analysis of a pilot scale microbial electrolysis cell for hydrogen production using urban wastewater. Energy Convers. Manag. 193, 52-63.

[22] Chen, S., Sun, Z., Zhang, Q., Hu, J., Xiang, W., 2017. Steam gasification of sewage sludge with $\mathrm{CaO}$ as $\mathrm{CO}_{2}$ sorbent for hydrogen-rich syngas production. Biomass Bioenergy. 107, 52-62.

[23] Cheng, Y.W., Lee, Z.S., Chong, C.C., Khan, M.R., Cheng, C.K., Ng, K.H., Hossain, S.S., 2019. Hydrogen-rich syngas production via steam reforming of palm oil mill effluent (POME)-a thermodynamics analysis. Int. J. Hydrogen Energy. 44(37), 20711-20724.
[24] Chiang, K.Y., Lu, C.H., Liao, C.K., Hsien-Ruen Ger, R., 2016 Characteristics of hydrogen energy yield by co-gasified of sewage sludge and paper-mill sludge in a commercial scale plant. Int. J. Hydrogen Energy. 41(46), 21641-21648.

[25] Cho, M.H., Mun, T.Y., Kim, J.S., 2013. Air gasification of mixed plastic wastes using calcined dolomite and activated carbon in a twostage gasifier to reduce tar. Energy. 53, 299-305.

[26] Cho, M.H., Mun, T.Y., Choi, Y.K., Kim, J.S., 2014. Two-stage air gasification of mixed plastic waste: Olivine as the bed material and effects of various additives and a nickel-plated distributor on the tar removal. Energy. 70, 128-134

[27] Cho, M.H., Choi, Y.K., Kim, J.S., 2015. Air gasification of PVC (polyvinyl chloride)-containing plastic waste in a two-stage gasifier using Ca-based additives and Ni-loaded activated carbon for the production of clean and hydrogen-rich producer gas. Energy. 87, 586593.

[28] Choi, Y.K., Cho, M.H., Kim, J.S., 2015. Steam/oxygen gasification of dried sewage sludge in a two-stage gasifier: effects of the steam to fuel ratio and ash of the activated carbon on the production of hydrogen and tar removal. Energy. 91, 160-167.

[29] Chun, Y.N., Song, H.G., 2020. Microwave-induced carbon-CO gasification for energy conversion. Energy. 190, 116386.

[30] Cormos, C.C., 2013. Assessment of flexible energy vectors polygeneration based on coal and biomass/solid wastes co-gasification with carbon capture. Int. J. Hydrogen Energy. 38(19), 7855-7866.

[31] Dashtestani, F., Nusheh, M., Siriwongrungson, V., Hongrapipat, J., Materic, V., Pang, S., 2021. Effect of $\mathrm{H}_{2} \mathrm{~S}$ and $\mathrm{NH}_{3}$ in biomass gasification producer gas on $\mathrm{CO}_{2}$ capture performance of an innovative $\mathrm{CaO}$ and $\mathrm{Fe}_{2} \mathrm{O}_{3}$ based sorbent. Fuel. 295, 120586

[32] Demirbas, A., 2016. Comparison of thermochemical conversion processes of biomass to hydrogen-rich gas mixtures. Energy Sources Part A. 38(20), 2971-2976.

[33] Demirbass, A., 2005. Thermochemical conversion of hazelnut shell to gaseous products for production of hydrogen. Energy sources. 27(4), 339-347.

[34] Djebabra, D., Dessaux, O., Goudmand, P., 1991. Coal gasification by microwave plasma in water vapour. Fuel. 70(12), 1473-1475

[35] Domínguez, A., Fernández, Y., Fidalgo, B., Pis, J.J., Menéndez, J.A. 2007. Biogas to syngas by microwave-assisted dry reforming in the presence of char. Energy Fuels. 21(4), 2066-2071.

[36] Đurišić-Mladenović, N., Škrbić, B.D., Zabaniotou, A., 2016 Chemometric interpretation of different biomass gasification processes based on the syngas quality: assessment of crude glycerol co-gasification with lignocellulosic biomass. Renew. Sust. Energy Rev. 59, 649-661.

[37] Edreis, E.M., Luo, G., Li, A., Xu, C., Yao, H., 2014. Synergistic effects and kinetics thermal behaviour of petroleum coke/biomass blends during $\mathrm{H}_{2} \mathrm{O}$ co-gasification. Energy Convers. Manage. 79 , 355-366.

[38] Effendi, A., Hellgardt, K., Zhang, Z.G., Yoshida, T., 2003. Characterisation of carbon deposits on $\mathrm{Ni} / \mathrm{SiO}_{2}$ in the reforming of $\mathrm{CH}_{4}-\mathrm{CO}_{2}$ using fixed-and fluidised-bed reactors. Catal. Commun. 4(4), 203-207.

[39] Elif, D., Nezihe, A., 2016. Hydrogen production by supercritical water gasification of fruit pulp in the presence of $\mathrm{Ru} / \mathrm{C}$. Int. J. Hydrogen Energy. 41(19), 8073-8083.

[40] Emami-Taba, L., Irfan, M.F., Daud, W.A.M.W., Chakrabarti, M.H., Emami Taba, L., Irfan, M.F., Wan Daud, W.A.M., Chakrabarti, M.H., 2012. The effect of temperature on various parameters in coal biomass and CO-gasification: a review. Renew. Sust. Energy Rev. $16(8), 5584-5596$.

[41] Emami-Taba, L., Irfan, M.F., Wan Daud, W.M.A., Chakrabarti, M.H., 2013. Fuel blending effects on the co-gasification of coal and biomass-a review. Biomass Bioenergy. 57, 249-263.

[42] Fermoso, J., Corbet, T., Ferrara, F., Pettinau, A., Maggio, E., Sanna A., 2018. Synergistic effects during the co-pyrolysis and cogasification of high volatile bituminous coal with microalgae. Energy Convers. Manag. 164, 399-409.

[43] Fremaux, S., Beheshti, S.M., Ghassemi, H., Shahsavan-Markadeh, R. 2015. An experimental study on hydrogen-rich gas production via 
steam gasification of biomass in a research-scale fluidized bed. Energy Convers. Manag. 91, 427-432.

[44] Gai, C., Guo, Y., Liu, T., Peng, N., Liu, Z., 2016. Hydrogen-rich gas production by steam gasification of hydrochar derived from sewage sludge. Int. J. Hydrogen Energy. 41(5), 3363-3372.

[45] Gao, M., Yang, Z., Wang, Y., Bai, Y., Li, F., Xie, K., 2017. Impact of calcium on the synergistic effect for the reactivity of coal char gasification in $\mathrm{H}_{2} \mathrm{O} / \mathrm{CO}_{2}$ mixtures. Fuel. 189, 312-321.

[46] Garcia, G., Arauzo, J., Gonzalo, A., Sanchez, J.L., Abrego, J., 2013. Influence of feedstock composition in fluidised bed co-gasification of mixtures of lignite, bituminous coal and sewage sludge. Chem. Eng. J. 222, 345-352.

[47] Gil-Lalaguna, N., Sánchez, J.L., Murillo, M.B., Rodríguez, E., Gea, G., 2014. Air-steam gasification of sewage sludge in a fluidized bed. Influence of some operating conditions. Chem. Eng. J. 248, 373-382.

[48] Granados-Pichardo, A., Granados-Correa, F., Sánchez-Mendieta, V., Hernández-Mendoza, H., 2020. New CaO-based adsorbents prepared by solution combustion and high-energy ball-milling processes for $\mathrm{CO}_{2}$ adsorption: Textural and structural influences. Arab. J. Chem. 13(1), 171183

[49] Guler, M., Dogu, T., Varisli, D., 2017. Hydrogen production over molybdenum loaded mesoporous carbon catalysts in microwave heated reactor system. Appl. Catal., B. 219, 173-182.

[50] Hamad, M.A., Radwan, A.M., Heggo, D.A., Moustafa, T., 2016. Hydrogen rich gas production from catalytic gasification of biomass. Renew. Energy. 85, 1290-1300.

[51] Haque, K.E., 1999. Microwave energy for mineral treatment processes-a brief review. Int. J. Miner. Process. 57(1), 1-24.

[52] He, C., Chen, C.L., Giannis, A., Yang, Y., Wang, J.Y., 2014. Hydrothermal gasification of sewage sludge and model compounds for renewable hydrogen production: a review. Renew. Sust. Energy Rev. 39, 1127-1142.

[53] Ho, G.S., Faizal, H.M., Ani, F.N., 2017. Microwave induced plasma for solid fuels and waste processing: a review on affecting factors and performance criteria. Waste Manage. 69, 423-430.

[54] Hosseinzadeh, A., Zhou, J.L., Li, X., Afsari, M., Altaee, A., 2022. Techno-economic and environmental impact assessment of hydrogen production processes using bio-waste as renewable energy resource. Renew. Sust. Energy Rev. 156, 111991.

[55] Hrycak, B., Czylkowski, D., Miotk, R., Dors, M., Jasinski, M., Mizeraczyk, J., 2014. Application of atmospheric pressure microwave plasma source for hydrogen production from ethanol. Int. J. Hydrogen Energy. 39(26), 14184-14190.

[56] Hu, B., Huang, Q., Buekens, A., Chi, Y., Yan, J., 2017. Co-gasification of municipal solid waste with high alkali coal char in a three-stage gasifier. Energy Convers. Manag. 153, 473-481

[57] Hu, J., Li, C., Guo, Q., Dang, J., Zhang, Q., Lee, D.J., Yang, Y., 2018a. Syngas production by chemical-looping gasification of wheat straw with Fe-based oxygen carrier. Bioresour. Technol. 263, 273-279.

[58] Hu, Z., Jiang, E., Ma, X., 2018b. Microwave pretreatment on microalgae: effect on thermo-gravimetric analysis and kinetic characteristics in chemical looping gasification. Energy Convers. Manag. 160, 375-383.

[59] Huang, Y.W., Chen, M.Q., Li, Q.H., Xing, W., 2018. Hydrogen-rich syngas produced from co-gasification of wet sewage sludge and torrefied biomass in self-generated steam agent. Energy. 161, 202-213.

[60] Hunt, J., Ferrari, A., Lita, A., Crosswhite, M., Ashley, B., Stiegman, A.E., 2013. Microwave-specific enhancement of the carbon-carbon dioxide (Boudouard) reaction. J. Phys. Chem. C. 117(51), 26871-26880.

[61] Inayat, A., Tariq, R., Khan, Z., Ghenai, C., Kamil, M., Jamil, F., Shanableh, A., 2020. A comprehensive review on advanced thermochemical processes for bio-hydrogen production via microwave and plasma technologies. Biomass Convers. Biorefin. 1-10.

[62] Inayat, M., Sulaiman, S.A., Kurnia, J.C., Shahbaz, M., 2019. Effect of various blended fuels on syngas quality and performance in catalytic cogasification: a review. Renew. Sust. Energy Rev. 105, 252-267.

[63] Irfan, M., Li, A., Zhang, L., Ji, G., Gao, Y., 2021. Catalytic gasification of wet municipal solid waste with $\mathrm{HfO}_{2}$ promoted $\mathrm{Ni}-\mathrm{CaO}$ catalyst for $\mathrm{H}_{2}-$ rich syngas production. Fuel. 286, 119408

[64] Jie, W.S., Abdullah, H., Yusof, N., Abbas, Z., 2015. Dielectric properties of oil palm trunk core. J. Clean Energy Technol. 3(6), 3-8.
[65] Kai, X., Li, R., Yang, T., Shen, S., Ji, Q., Zhang, T., 2017. Study on the co-pyrolysis of rice straw and high density polyethylene blends using TG-FTIR-MS. Energy Convers. Manag. 146, 20-33.

[66] Kapusta, K., Stańczyk, K., Wiatowski, M., Chećko, J., 2013. Environmental aspects of a field-scale underground coal gasification trial in a shallow coal seam at the Experimental Mine Barbara in Poland. Fuel. 113, 196-208.

[67] Ke, C., Zhang, Y., Gao, Y., Pan, Y., Li, B., Wang, Y., Ruan, R., 2019. Syngas production from microwave-assisted air gasification of biomass: part 1 model development. Renew. Energy. 140, 772778.

[68] Koido, K., Kurosawa, K., Endo, K., Sato, M., 2021. Catalytic and inhibitory roles of $\mathrm{K}$ and $\mathrm{Ca}$ in the pyrolysis and $\mathrm{CO}_{2}$ or steam gasification of Erianthus, and their effects on co-gasification performance. Biomass Bioenergy. 154, 106257

[69] Lahijani, P., Zainal, Z.A., Mohamed, A.R., Mohammadi, M., 2014 Microwave-enhanced $\mathrm{CO}_{2}$ gasification of oil palm shell char Bioresour. Technol. 158, 193-200

[70] Lepage, T., Kammoun, M., Schmetz, Q., Richel, A., 2021. Biomass to-hydrogen: a review of main routes production, processes evaluation and techno-economical assessment. Biomass Bioenergy. 144,105920

[71] Li, S., Zheng, H., Zheng, Y., Tian, J., Jing, T., Chang, J.S., Ho, S.H., 2019. Recent advances in hydrogen production by thermo-catalytic conversion of biomass. Int. J. Hydrogen Energy. 44(28), 1426614278 .

[72] Lin, K.C., Lin, Y.C., Hsiao, Y.H., 2014a. Microwave plasma studies of Spirulina algae pyrolysis with relevance to hydrogen production. Energy. 64, 567-574

[73] Lin, Y.C., Wu, T.Y., Liu, W.Y., Hsiao, Y.H., 2014b. Production of hydrogen from rice straw using microwave-induced pyrolysis. Fuel $119,21-26$

[74] Liu, Q., He, H., Li, H., Jia, J., Huang, G., Xing, B., Zhang, C., Cao, Y., 2019. Characteristics and kinetics of coal char steam gasification under microwave heating. Fuel. 256, 115899

[75] Liu, Y., Wang, T., Zhang, X., Hu, X., Liu, T., Guo, Q., 2021. Chemical looping staged conversion of microalgae with calcium ferrite as oxygen carrier: pyrolysis and gasification characteristics. J. Anal. Appl. Pyrolysis. 156, 105129

[76] Lopes, M.H., Pinto, F., Crujeira, A.T., Andre’, R., Dias, M. rio, Gulyurtlu, I., Cabrita, I., 2006. Environmental impact of sewage sludge co-gasification with coal. Turbo Expo Power Land, Sea, Air. 42371, 401-408

[77] Lopez, G., Erkiaga, A., Amutio, M., Bilbao, J., Olazar, M., 2015. Effect of polyethylene co-feeding in the steam gasification of biomass in a conical spouted bed reactor. Fuel. 153, 393-401.

[78] Luo, M., Zhang, H., Wang, S., Cai, J., Qin, Y., Zhou, L., 2022. Syngas production by chemical looping co-gasification of rice husk and coal using an iron-based oxygen carrier. Fuel. 309, 122100.

[79] Lupa, C.J., Wylie, S.R., Shaw, A., Al-Shamma'a, A., Sweetman, A.J. Herbert, B.M.J., 2013. Gas evolution and syngas heating value from advanced thermal treatment of waste using microwave-induced plasma. Renew. Energy. 50, 1065-1072.

[80] Mallick, D., Mahanta, P., Moholkar, V.S., 2017. Co-gasification of coal and biomass blends: chemistry and engineering. Fuel. 204, 106 128.

[81] Mastellone, M.L., Zaccariello, L., Arena, U., 2010. Co-gasification of coal, plastic waste and wood in a bubbling fluidized bed reactor. Fuel. 89(10), 2991-3000.

[82] Mastuli, M.S., Kamarulzaman, N., Kasim, M.F., Mahat, A.M., Matsumura, Y., Taufiq-Yap, Y.H., 2019. Catalytic supercritical water gasification of oil palm frond biomass using nanosized $\mathrm{MgO}$ doped Zn catalysts. J. Supercrit. Fluids. 154, 104610

[83] Menéndez, J.A., Domínguez, A., Inguanzo, M., Pis, J.J., 2005. Microwave-induced drying, pyrolysis and gasification (MWDPG) of sewage sludge: vitrification of the solid residue. J. Anal. Appl. Pyrolysis. 74(1-2), 406-412

[84] Menéndez, J.A., Domínguez, A., Fernández, Y., Pis, J.J., 2007. Evidence of self-gasification during the microwave-induced pyrolysis of coffee hulls. Energy Fuels. 21(1), 373-378 
[85] Metaxas, A.C., Meredith, R.J., 1983. Industrial microwave heating. IET.

[86] Moher, D., Liberati, A., Tetzlaff, J., Altman, D.G., Group, P., 2009. Reprint-preferred reporting items for systematic reviews and metaanalyses: the PRISMA statement. Phys. Ther. 89(9), 873-880.

[87] Muradov, N., Smith, F., Huang, C., Ali, T., 2006a. Autothermal catalytic pyrolysis of methane as a new route to hydrogen production with reduced $\mathrm{CO}_{2}$ emissions. Catal. Today. 116(3), 281-288.

[88] Muradov, N., Smith, F., Huang, C., T-Raissi, A., 2006b. Decentralized production of hydrogen from hydrocarbons with reduced $\mathrm{CO}_{2}$ emission.

[89] Nanda, S., Isen, J., Dalai, A.K., Kozinski, J.A., 2016. Gasification of fruit wastes and agro-food residues in supercritical water. Energy Convers. Manag. 110, 296-306.

[90] Nanda, S., Rana, R., Hunter, H.N., Fang, Z., Dalai, A.K., Kozinski, J.A., 2019. Hydrothermal catalytic processing of waste cooking oil for hydrogen-rich syngas production. Chem. Eng. Sci. 195, 935-945.

[91] Ng, W.C., You, S., Ling, R., Gin, K.Y.H., Dai, Y., Wang, C.H., 2017. Co-gasification of woody biomass and chicken manure: syngas production, biochar reutilization, and cost-benefit analysis. Energy. 139, $732-742$.

[92] Nguyen, V.T., Chiang, K.Y., 2021. Sewage and textile sludge cogasification using a lab-scale fluidized bed gasifier. Int. J. Hydrogen Energy.

[93] Okolie, J.A., Rana, R., Nanda, S., Dalai, A.K., Kozinski, J.A., 2019. Supercritical water gasification of biomass: a state-of-the-art review of process parameters, reaction mechanisms and catalysis. Sustain. Energy Fuels. 3(3), 578-598

[94] Okolie, J.A., Nanda, S., Dalai, A.K., Berruti, F., Kozinski, J.A., 2020a. A review on subcritical and supercritical water gasification of biogenic, polymeric and petroleum wastes to hydrogen-rich synthesis gas. Renew. Sustain. Energy Rev. 119, 109546.

[95] Okolie, J.A., Nanda, S., Dalai, A.K., Kozinski, J.A., 2020b. Hydrothermal gasification of soybean straw and flax straw for hydrogenrich syngas production: experimental and thermodynamic modeling. Energy Convers. Manag. 208, 112545.

[96] Okolie, J.A., Nanda, S., Dalai, A.K., Kozinski, J.A., 2020c. Optimization and modeling of process parameters during hydrothermal gasification of biomass model compounds to generate hydrogen-rich gas products. Int. J. Hydrogen Energy. 45(36), 18275-18288

[97] Oliveira, A.M., Beswick, R.R., Yan, Y., 2021. A green hydrogen economy for a renewable energy society. Curr. Opin. Chem. Eng. 33, 100701.

[98] Omar, R., Idris, A., Yunus, R., Khalid, K., Isma, M.I.A., 2011. Characterization of empty fruit bunch for microwave-assisted pyrolysis. Fuel. 90(4), 1536-1544

[99] Pandey, B., Prajapati, Y.K., Sheth, P.N., 2019. Recent progress in thermochemical techniques to produce hydrogen gas from biomass: a state of the art review. Int. J. Hydrogen Energy. 44(47), 25384-25415.

[100]Papalas, T., Polychronidis, I., Antzaras, A.N., Lemonidou, A.A., 2021. Enhancing the intermediate-temperature $\mathrm{CO}_{2}$ capture efficiency of mineral $\mathrm{MgO}$ via molten alkali nitrates and $\mathrm{CaCO}_{3}$ : characterization and sorption mechanism. J. $\mathrm{CO}_{2}$ Util. 50, 101605.

[101]Parthasarathy, P., Narayanan, K.S., 2014. Hydrogen production from steam gasification of biomass: Influence of process parameters on hydrogen yield-a review. Renew. Energy. 66, 570-579.

[102]Parvez, A.M., Wu, T., Afzal, M.T., Mareta, S., He, T., Zhai, M., 2019. Conventional and microwave-assisted pyrolysis of gumwood: a comparison study using thermodynamic evaluation and hydrogen production. Fuel Process. Technol. 184, 1-11.

[103]Peng, L., Wang, Y., Lei, Z., Cheng, G., 2012. Co-gasification of wet sewage sludge and forestry waste in situ steam agent. Bioresour. Technol. $114,698-702$

[104]Pinto, F., Franco, C., André, R.N., Miranda, M., Gulyurtlu, I., Cabrita, I., 2002. Co-gasification study of biomass mixed with plastic wastes. Fuel. 81(3), 291-297.

[105]Pinto, F., André, R.N., Franco, C., Lopes, H., Gulyurtlu, I., Cabrita, I., 2009. Co-gasification of coal and wastes in a pilot-scale installation 1 : effect of catalysts in syngas treatment to achieve tar abatement. Fuel. $88(12), 2392-2402$
[106]Pinto, F., André, R.N., Carolino, C., Miranda, M., 2014. Hot treatment and upgrading of syngas obtained by co-gasification of coal and wastes. Fuel Process. Technol. 126, 19-29.

[107]Qian, L., Wang, S., Xu, D., Guo, Y., Tang, X., Wang, L., 2016. Treatment of municipal sewage sludge in supercritical water: a review. Water Res. 89, 118-131.

[108]Raheem, A., Cui, X., Mangi, F.H., Memon, A.A., Ji, G., Cheng, B. Dong, W., Zhao, M., 2020. Hydrogen-rich energy recovery from microalgae (lipid-extracted) via steam catalytic gasification. Algal Res. 52, 102102

[109]Ramos, A., Monteiro, E., Silva, V., Rouboa, A., 2018. Co-gasification and recent developments on waste-to-energy conversion: a review. Renew. Sust. Energy Rev. 81, 380-398.

[110]Ramos, A., Teixeira, C.A., Rouboa, A., 2019. Environmental assessment of municipal solid waste by two-stage plasma gasification. Energies. 12(1), 137.

[111]Rostrupnielsen, J.R., Hansen, J.H.B., 1993. $\mathrm{CO}_{2}$-reforming of methane over transition metals. J. Catal. 144(1), 38-49.

[112] Salema, A.A., Yeow, Y.K., Ishaque, K., Ani, F.N., Afzal, M.T. Hassan, A., 2013. Dielectric properties and microwave heating of oil palm biomass and biochar. Ind. Crops Prod. 50, 366-374.

[113]Schmid, M., Hafner, S., Scheffknecht, G., 2021. Experimenta parameter study on synthesis gas production by steam-oxygen fluidized bed gasification of sewage sludge. Appl. Sci. 11(2), 1-27.

[114] Sekiguchi, H., Orimo, T., 2004. Gasification of polyethylene using steam plasma generated by microwave discharge. Thin Solid Films. 457(1), 44-47.

[115]Shahabuddin, M., Krishna, B.B., Bhaskar, T., Perkins, G., 2020 Advances in the thermo-chemical production of hydrogen from biomass and residual wastes: summary of recent techno-economic analyses. Bioresour. Technol. 299, 122557.

[116]Shahbaz, M., Al-Ansari, T., Aslam, M., Khan, Z., Inayat, A., Athar, M., Naqvi, S.R., Ahmed, M.A., McKay, G., 2020a. A state of the art review on biomass processing and conversion technologies to produce hydrogen and its recovery via membrane separation. Int. J. Hydrogen Energy. 45(30), 15166-15195.

[117]Shahbaz, M., Al-Ansari, T., Inayat, M., Sulaiman, S.A., Parthasarathy, P., McKay, G., 2020b. A critical review on the influence of process parameters in catalytic co-gasification: curren performance and challenges for a future prospectus. Renew. Sust. Energy Rev. 134, 110382.

[118] Sheikhdavoodi, M.J., Almassi, M., Ebrahimi-Nik, M., Kruse, A., Bahrami, H., 2015. Gasification of sugarcane bagasse in supercritical water; evaluation of alkali catalysts for maximum hydrogen production. J. Energy Inst. 88(4), 450-458.

[119]Shi, K., Yan, J., Luo, X., Lester, E., Wu, T., 2017. Microwaveassisted pyrolysis of bamboo coupled with reforming by activated carbon for the production of hydrogen-rich syngas. Energy Procedia. $142,1640-1646$

[120]Shi, W., Laabs, M., Reinmöller, M., Bai, J., Guhl, S., Kong, L., Li, H., Meyer, B., Li, W., 2021. In-situ analysis of the effect of $\mathrm{CaO} / \mathrm{Fe}_{2} \mathrm{O}_{3}$ addition on ash melting and sintering behavior for slagging-type applications. Fuel. 285, 119090.

[121]Shin, D.H., Hong, Y.C., Lee, S.J., Kim, Y.J., Cho, C.H., Ma, S.H., Chun, S.M., Lee, B.J., Uhm, H.S., 2013. A pure steam microwave plasma torch: gasification of powdered coal in the plasma. Surf. Coatings Technol. 228, S520-S523.

[122]Smoliński, A., Howaniec, N., 2016. Co-gasification of coal/sewage sludge blends to hydrogen-rich gas with the application of simulated high temperature reactor excess heat. Int. J. Hydrogen Energy. 41(19), 8154-8158

[123]Song, T., Wu, J., Shen, L., Xiao, J., 2012. Experimental investigation on hydrogen production from biomass gasification in interconnected fluidized beds. Biomass Bioenergy. 36, 258-267.

[124]Stańczyk, K., Kapusta, K., Wiatowski, M., Świądrowski, J. Smoliński, A., Rogut, J., Kotyrba, A., 2012. Experimental simulation of hard coal underground gasification for hydrogen production. Fuel. 91(1), 40-50 
[125]State, R.N., Volceanov, A., Muley, P., Boldor, D., 2019. A review of catalysts used in microwave assisted pyrolysis and gasification. Bioresour. Technol. 277, 179-194.

[126]Stefanidis, G.D., Munoz, A.N., Sturm, G.S.J., Stankiewicz, A., 2014. A helicopter view of microwave application to chemical processes: reactions, separations, and equipment concepts. Rev. Chem. Eng. 30(3), 233-259.

[127]Sturm, G.S.J., Muñoz, A.N., Aravind, P. V, Stefanidis, G.D., 2016. Microwave-driven plasma gasification for biomass waste treatment at miniature scale. IEEE Trans. Plasma Sci. 44(4), 670-678.

[128]Su, H., Yan, M., Wang, S., 2022. Recent advances in supercritical water gasification of biowaste catalyzed by transition metal-based catalysts for hydrogen production. Renew. Sust. Energy Rev. 154, 111831.

[129]Suard, C., Mourel, R.M., Cerdan, B., Bart, G., Feinberg, M.H., 1996. Modeling energy transfer in a focused microwave digestor. Anal. Chim. Acta. 318(3), 261-273.

[130]Sun, Z., Toan, S., Chen, S., Xiang, W., Fan, M., Zhu, M., Ma, S., 2017. Biomass pyrolysis-gasification over $\mathrm{Zr}$ promoted CaO-HZSM- 5 catalysts for hydrogen and bio-oil co-production with $\mathrm{CO}_{2}$ capture. Int. J. Hydrogen Energy. 42(25), 16031-16044.

[131]Thiagarajan, J., Srividhya, P.K., Balasubramanian, P., 2020. Thermochemical behaviors and co-gasification kinetics of palm kernel shells with bituminous coal. Biomass Convers. Biorefin. 10(3), 697-706.

[132]Tungalag, A., Lee, B.J., Yadav, M., Akande, O., 2020. Yield prediction of MSW gasification including minor species through ASPEN plus simulation. Energy. 198, 117296.

[133]Tursun, Y., Xu, S., Wang, C., Xiao, Y., Wang, G., 2016. Steam cogasification of biomass and coal in decoupled reactors. Fuel Process. Technol, 141, 61-67.

[134]Udomsirichakorn, J., Salam, P.A., 2014. Review of hydrogen-enriched gas production from steam gasification of biomass: the prospect of CaObased chemical looping gasification. Renew. Sust. Energy Rev. 30, $565-$ 579.

[135]Valero, A., Usón, S., 2006. Oxy-co-gasification of coal and biomass in an integrated gasification combined cycle (IGCC) power plant. Energy. 31(10-11), 1643-1655

[136]Vecten, S., Wilkinson, M., Bimbo, N., Dawson, R., Herbert, B.M.J., 2021. Hydrogen-rich syngas production from biomass in a steam microwave-induced plasma gasification reactor. Bioresour. Technol. 337, 125324

[137]Wang, J., Cheng, G., You, Y., Xiao, B., Liu, S., He, P., Guo, D., Guo, X., Zhang, G., 2012. Hydrogen-rich gas production by steam gasification of municipal solid waste (MSW) using $\mathrm{NiO}$ supported on modified dolomite. Int. J. Hydrogen Energy. 37(8), 6503-6510.

[138]Wang, J., Chen, J., Liu, J., Liu, H., Wang, M., Cheng, J., 2022. Synergistic effects of mixing waste activated carbon and coal in coslurrying and $\mathrm{CO}_{2}$ co-gasification. Powder Technol. 395, 883-892.

[139]Wang, M., Wan, Y., Guo, Q., Bai, Y., Yu, G., Liu, Y., Zhang, H., Zhang, S., Wei, J., 2021. Brief review on petroleum coke and biomass/coal cogasification: syngas production, reactivity characteristics, and synergy behavior. Fuel. 304, 121517

[140]Wang, Z., Ouyang, P., Cui, L., Zong, B., Wu, G., Zhang, Y., 2020. Valorizing petroleum coke into hydrogen-rich syngas through Kpromoted catalytic steam gasification. J. Energy Inst. 93(6), 2544-2549.

[141]Wei, J., Gong, Y., Guo, Q., Chen, X., Ding, L., Yu, G., 2019. A mechanism investigation of synergy behaviour variations during blended char co-gasification of biomass and different rank coals. Renew. Energy. 131, 597-605.

[142]Wnukowski, M., van de Steeg, A.W., Hrycak, B., Jasiński, M., van Rooij, G.J., 2021. Influence of hydrogen addition on methane coupling in a moderate pressure microwave plasma. Fuel. 288, 119674.

[143]Wolfesberger, U., Aigner, I., Hofbauer, H., 2009. Tar content and composition in producer gas of fluidized bed gasification of woodinfluence of temperature and pressure. Environ. Prog. Sust. Energy 28(3), 372-379

[144]Wu, C., Budarin, V.L., Wang, M., Sharifi, V., Gronnow, M.J., Wu, Y., Swithenbank, J., Clark, J.H., Williams, P.T., 2015. $\mathrm{CO}_{2}$ gasification of bio-char derived from conventional and microwave pyrolysis. Appl. Energy. 157, 533-539.
[145]Xiang, X., Gong, G., Shi, Y., Cai, Y., Wang, C., 2018 Thermodynamic modeling and analysis of a serial composite process for biomass and coal co-gasification. Renew. Sust. Energy Rev. 82 $2768-2778$

[146]Xiao, N., Luo, H., Wei, W., Tang, Z., Hu, B., Kong, L., Sun, Y., 2015. Microwave-assisted gasification of rice straw pyrolytic biochar promoted by alkali and alkaline earth metals. J. Anal. Appl. Pyrolysis. $112,173-179$

[147]Xiao, X., Meng, X., Le, D.D., Takarada, T., 2011. Two-stage steam gasification of waste biomass in fluidized bed at low temperature: parametric investigations and performance optimization. Bioresour. Technol. 102(2), 1975-1981

[148]Xiao, Y., Watson, M., 2019. Guidance on conducting a systematic literature review. J. Plann. Educ. Res. 39(1), 93-112.

[149]Xie, Q., Borges, F.C., Cheng, Y., Wan, Y., Li, Y., Lin, X., Liu, Y. Hussain, F., Chen, P., Ruan, R., 2014. Fast microwave-assisted catalytic gasification of biomass for syngas production and tar removal. Bioresour. Technol. 156, 291-296.

[150]Xu, C., Hu, S., Xiang, J., Zhang, L., Sun, L., Shuai, C., Chen, Q., He, L., Edreis, E.M.A., 2014. Interaction and kinetic analysis for coal and biomass co-gasification by TG-FTIR. Bioresour. Technol. 154, 313 321.

[151]Xu, F., Xing, X., Gao, S., Zhang, W., Zhu, L., Wang, Y., Chen, J. Chen, H., Zhu, Y., 2021. Direct chemical looping gasification of pine sawdust using $\mathrm{Fe}_{2} \mathrm{O}_{3}$-rich sludge ash as an oxygen carrier: therma conversion characteristics, product distributions, and gasification performances. Fuel. 304, 121499.

[152]Yan, B., Jiao, L., Li, J., Zhu, X., Ahmed, S., Chen, G., 2021. Investigation on microwave torrefaction: parametric influence, TGMS-FTIR analysis, and gasification performance. Energy. 220, 119794.

[153]Yang, C., Wang, S., Yang, J., Xu, D., Li, Y., Li, J., Zhang, Y., 2020 Hydrothermal liquefaction and gasification of biomass and model compounds: a review. Green Chem. 22(23), 8210-8232.

[154]Yang, Y., Zhu, J., Yang, L., Zhu, Y., 2019. Co-gasification characteristics of scrap tyre with pine sawdust using thermogravimetric and a whole-tyre gasifier reactor. Energy Procedia. 158, 37-42.

[155]Yao, X., Zhou, H., Xu, K., Xu, Q., Li, L., 2019. Evaluation of the fusion and agglomeration properties of ashes from combustion of biomass, coal and their mixtures and the effects of $\mathrm{K}_{2} \mathrm{CO}_{3}$ additives. Fuel. 255, 115829 .

[156]Yoon, S.J., Lee, J.G.G., 2012. Hydrogen-rich syngas production through coal and charcoal gasification using microwave steam and air plasma torch. Int. J. Hydrogen Energy. 37(22), 17093-17100.

[157]Yoon, S.J., Lee, J.G.G., Huang, Y.F., Kuan, W.H., Chang, C.C. Tzou, Y.M., Yoon, S.J., Lee, J.G.G., 2013a. Catalytic and atmospheric effects on microwave pyrolysis of corn stover. Bioresour. Technol. 131, 274-280

[158]Yoon, S.J., Yun, Y.M., Seo, M.W., Kim, Y.K., Ra, H.W., Lee, J.G., 2013b. Hydrogen and syngas production from glycerol through microwave plasma gasification. Int. J. Hydrogen Energy. 38(34), 14559-14567.

[159]Yousef, S., Eimontas, J., Striūgas, N., Abdelnaby, M.A., 2021 Pyrolysis and gasification kinetic behavior of mango seed shells using TG-FTIR-GC-MS system under $\mathrm{N}_{2}$ and $\mathrm{CO}_{2}$ atmospheres. Renew. Energy. 173, 733-749.

[160]Zamri, A.A., Ong, M.Y., Nomanbhay, S., Show, P.L., Aiman, A. Ong, M.Y., Nomanbhay, S., Show, P.L., 2021. Microwave plasma technology for sustainable energy production and the electromagnetic interaction within the plasma system: a review. Environ. Res. 197, 111204.

[161]Zhang, D., Lu, L., Ren, Y., Jin, H., Wei, W., Cheng, Z., Guo, L., 2021 $\mathrm{K}_{2} \mathrm{CO}_{3}$-catalytic supercritical water gasification of coal with $\mathrm{NaAlO}_{2}$ addition to inhibit ash agglomeration and decrease the volatility of alkali metals. Fuel. 303, 121312

[162]Zhang, Q., Liu, H., Li, W., Xu, J., Liang, Q., 2012. Behavior of phosphorus during co-gasification of sewage sludge and coal. Energy Fuels. 26(5), 2830-2836 
[163]Zhang, Y., Ke, C., Fu, W., Cui, Y., Rehan, M.A., Li, B., 2020 a. Simulation of microwave-assisted gasification of biomass: a review. Renew. Energy. 154, 488-496.

[164]Zhang, Y., Chen, G., Wang, L., Tuo, K., Liu, S., 2020b. Microwaveassisted pyrolysis of low-rank coal with $\mathrm{K}_{2} \mathrm{CO}_{3}, \mathrm{CaCl}_{2}$, and $\mathrm{FeSO}_{4}$ catalysts. ACS Omega. 5(28), 17232-17241.

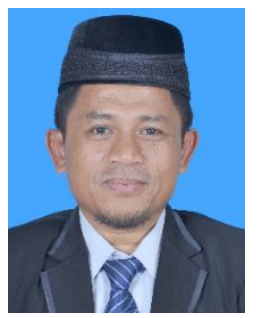

Suyitno is a Professor at Universitas Sebelas Maret in Indonesia. $\mathrm{He}$ is a lecturer at Universitas Sebelas Maret's Department of Mechanical Engineering. He received his Master's degree in Mechanical Engineering from the Bandung Institute of Technology in Indonesia. He received his Ph.D. from the Thermal Engineering Faculty at the Graz University of Technology in Austria. Suyitno did several works in the fields of renewable energy, pyrolysis, gasification, computational fluid dynamics, nanomaterials for energy, and dye-sensitized solar cells. He has around 30 publications published in peer-reviewed journals, with an $\mathrm{H}$-index of 11 . His Google Scholar research profile may be viewed at the following link: https://scholar.google.co.id/citations?user=9rhDrqcAAAAJ\&hl=en.

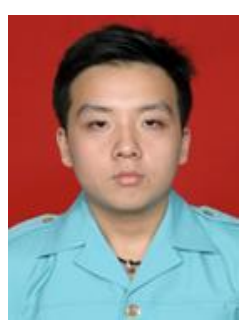

Albert Xaverio Ilyas is a mechanical engineering undergraduate student at Sebelas Maret University's Faculty of Engineering. His research interests are on sustainable and renewable energy, with a particular emphasis on gasification using experimental and simulation methods. He is working on gasification simulation using computational fluid dynamics.

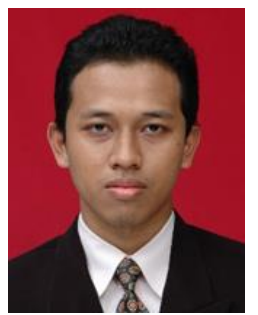

Mirza Yusuf is an Automotive Engineering Technology instructor at Universitas Muhammadiyah Yogyakarta in Indonesia. He holds a master's degree in Energy Conversion from Sebelas Maret University's Department of Mechanical Engineering in Indonesia. At PT MAK Indonesia, he is a registered engineer involved in medical device research studies. Mirza's research focuses on renewable energy and improved energy conversion materials. His Google Scholar research profile can be accessed at the following URL: https://scholar.google.co.id/citations?hl=en\&user=2mpJWWMAAAAJ.
[165]Zhao, K., Fang, X., Huang, Z., Wei, G., Zheng, A., Zhao, Z., 2021a. Hydrogen-rich syngas production from chemical looping gasification of lignite by using $\mathrm{NiFe}_{2} \mathrm{O}_{4}$ and $\mathrm{CuFe}_{2} \mathrm{O}_{4}$ as oxygen carriers. Fuel. 303,121269

[166]Zhao, X., Tian, Y., Guo, B., Sun, C., Zhou, P., Chen, G., Wang, W., Sun, J., Wang, P., Mao, Y., Song, Z., 2021b. Microwave steam gasification of semi-coke derived from co-pyrolysis of fungus chaff and lignite. Int. J. Coal Prep. Util. 41(11).

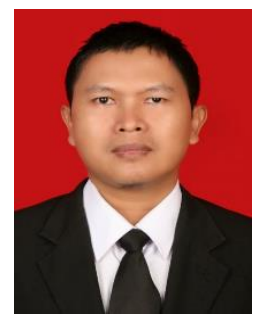

Imron Rosyadi is a $\mathrm{Ph} . \mathrm{D}$. candidate at the Department of Mechanical Engineering, Sebelas Maret University, Indonesia. He holds a Master of Science in Energy Engineering from Bandung Institute of Technology, Indonesia. He is currently a lecturer at the Department of Mechanical Engineering, University of Sultan Ageng Tirtayasa, Indonesia. Imron's research interests include (1) Pyrolysis, (2) Gasification, (3) Biofuel Production, and (4) Renewable Technologies. His research profile on Google Scholar can be found at the following link: https://scholar.google.co.id/citations?hl=en\&user=5RuLswcAAAAJ.

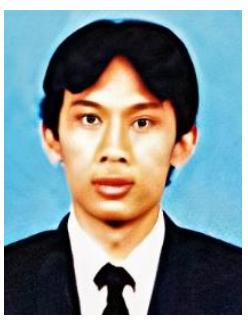

Andres Budiono is a Ph.D. candidate at the Department of Mechanical Engineering, Sebelas Maret University, Indonesia. He holds a Master's degree in Mechanical Engineering from the Toyohashi University of Technology in Japan. He is currently a lecturer at Universitas Kebangsaan Republik Indonesia's Department of Mechanical Engineering. (1) Separation, (2) Fluid Dynamics, (3) Computational Fluid Dynamics (CFD), (4) Geothermal, and (5) Renewable Energy are among Andres` research interests. His Google Scholar research profile can be accessed at the following URL:

https://scholar.google.co.id/citations?user=coEIdcAAAAAJ\&hl=en\&oi=s ra.

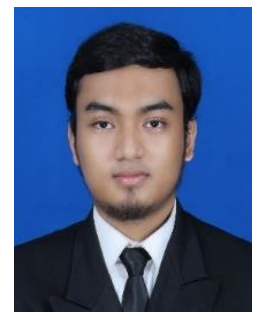

Afif Faishal is a master's student at Sebelas Maret University's Department of Mechanical Engineering. He graduated from Muhammadiyah University in Surakarta, Indonesia, with a Bachelor of Mechanical Engineering degree. Afif is currently a researcher at Muhammadiyah University in Surakarta, Indonesia. His research interests include (1) renewable energy, (2) biomass and municipal solid waste gasification, (3) techno economy, and (4) energy sustainability analysis. 